$$
\begin{aligned}
& \text { جامعـة المنصــورة } \\
& \text { كليــة النربية }
\end{aligned}
$$

\title{
واقع تحقيق التربية الاقتصادية لدي أطفال الروضة - دراسة هيدانية بمحافظة الدقهلية
}

$$
\begin{aligned}
& \text { إعداد } \\
& \text { اسماء محمد عبد العزيز عبده } \\
& \text { أ. د أثرف السعيد أحمد } \\
& \text { إثر اف } \\
& \text { أستاذ أصول التربية } \\
& \text { أ.د مهني ابر اهيم غنايم }
\end{aligned}
$$

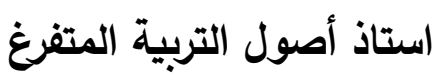

$$
\begin{aligned}
& \text { كلية التربية - جامعة المنصورة } \\
& \text { كلية التربية - جامعة المنصورة }
\end{aligned}
$$

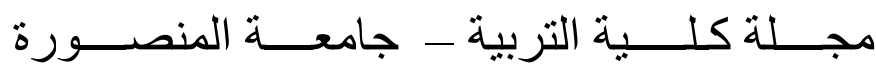

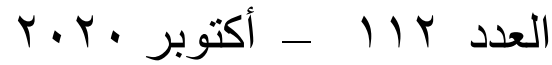

$$
\begin{aligned}
& \text { واقع تحقيق التربية الاقتصادية لدي أطفال الروضةد ـ ـ دراسة ميدانية } \\
& \text { بمحافظة الدقهلية }
\end{aligned}
$$




\section{اسماء محمد عبد العزيز عبده}

$$
\text { ملخص البحث: }
$$

هدف البحث إلى التعرف على واقع تحقيق التربية الاقتصادية لدي أطفال الروضة ـ وتحقيقًا لهدف

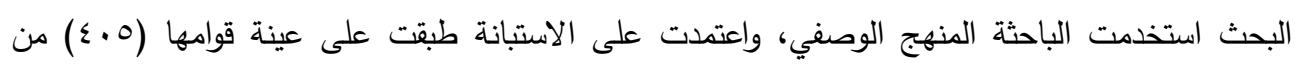

معلمات رياض الأطفال بمحافظة الدقهلية .

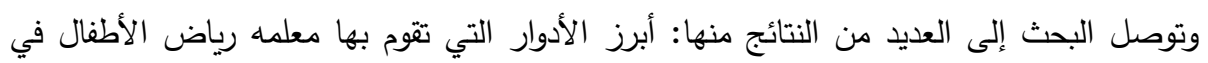

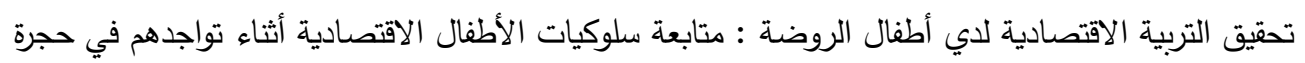

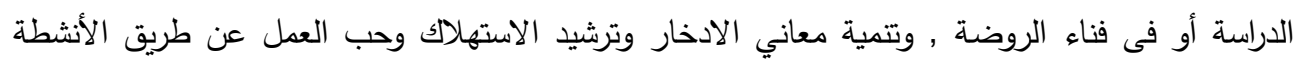

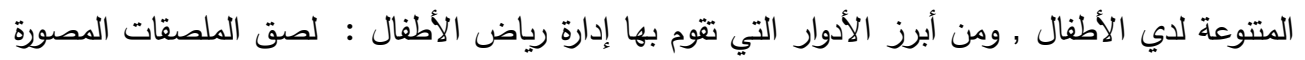

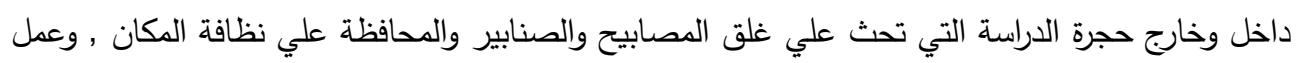

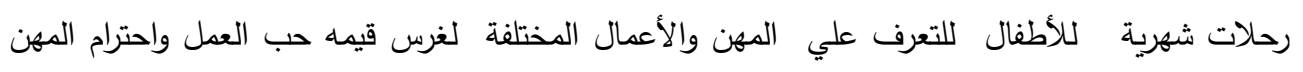

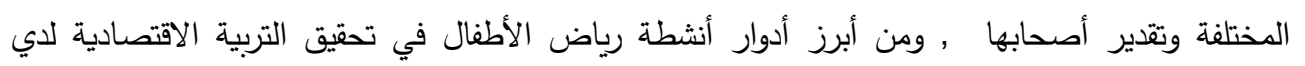

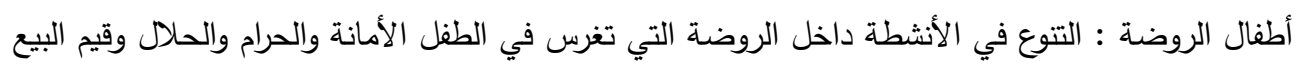

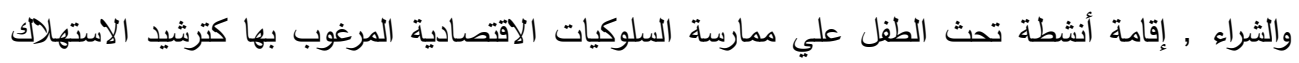

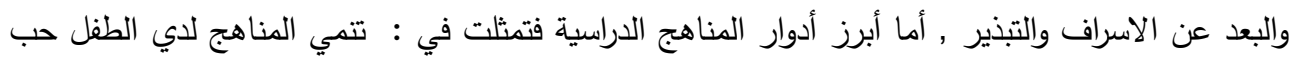

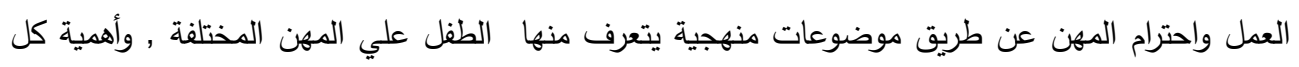

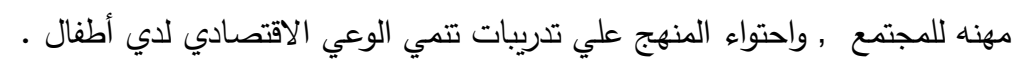

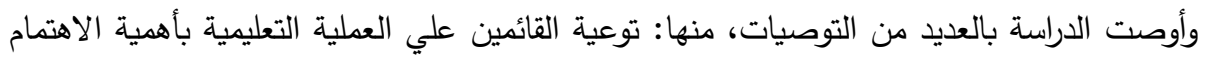

بالتربية الاقتصادية في مناهج الروضة , وتطوير مناهج الروضة بحيث تتمي وتدعم القيم الاقتصادية .

\section{Abstract :}

The aim of the research is to identify the reality of achieving economic education among kindergarten children. To achieve the aim of the research, the researcher used the descriptive method, and relied on a questionnaire applied to a sample of (405) kindergarten teachers in Dakahlia Governorate.

The research reached many results, including: The most prominent roles played by kindergarten teachers in achieving economic education among kindergarten children: Monitor children's economic behaviors while they are in the classroom or in the kindergarten, And developing the meanings of saving, rationalizing consumption and love of work through the 
various activities of children, Among the most prominent roles played by the kindergarten administration: Posting picture posters inside and outside the classroom urging you to turn off the lamps and faucets and maintain the cleanliness of the place, And making monthly trips for children to learn about different professions and businesses to instill the value of love of work and respect for different professions and appreciation of their owners, One of the most important roles of kindergarten activities in achieving economic education among kindergarten children : Diversity in activities within the kindergarten that instill in the child the trust, the forbidden and the halal, and the values of buying and selling, Establishing activities that encourage the child to practice desired economic behaviors such as rationalizing consumption and avoiding extravagance and waste, As for the most prominent roles of the school curriculum, it was represented in: Curricula develop in the child a love of work and respect for professions through methodological topics from which the child learns about the different professions, and the importance of each profession to society, and the curriculum contains training that develops economic awareness among children.

The study recommended several recommendations, including: educating those in charge of the educational process about the importance of paying attention to economic education in the kindergarten curriculum, and developing kindergarten curricula so that it develops and supports economic values.

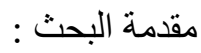

تعد مرحلة الطفولة من أهم المراحل في حياة الفرد والمجتمع حيث تتثكل فيها شخصية الفرد

وتتمو فيها السمات الأساسية المميزة له ، وبقدر الاهتمام الذى يوجه لهذه لهاه المرحلة بقدر ما ينشأ

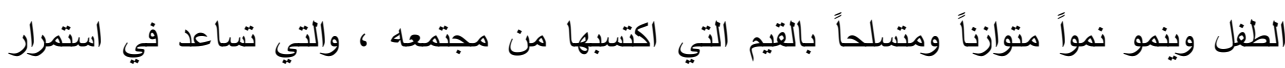

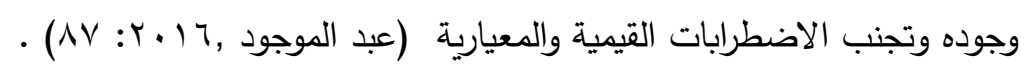

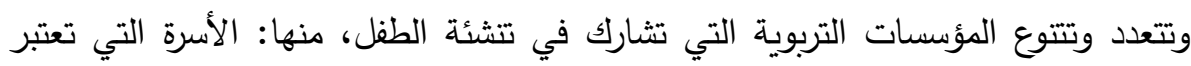

الأساس الأول في تتشئة الطفل، والروضة (المدرسة)، وجماعة الرفاق، ودور العبادة والأندية

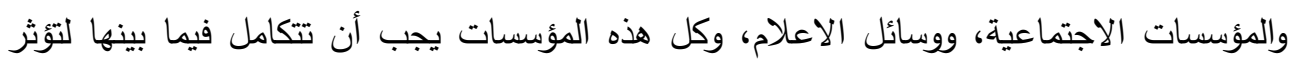

على نحو ايجابي ومخطط في تربية وتتثئة الطفل .

وتأتي الروضة في مقدمة المؤسات التربوية التي تقوم بتتمية مهارات الأطفال اللغوية

والعددية والفنية من خلال الأنشطة الفردية والجماعية وإنماء القدرة علي التنكير والابتكار والتخيل, 
وتعمل علي التتشئة الاجتماعية والصحية السليمة وعلي تلبية حاجات ومطالب النمو الخاصة في هذه المرحلة ليتمكن الطفل من تطوير ذاته وتكوين شخصيته السليمة , وعلي تكوين مفاهيم

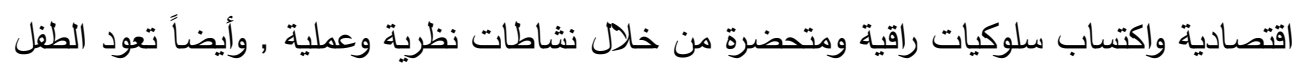

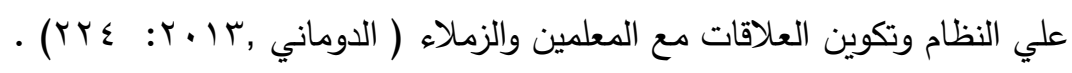

ومن دواعي القول بضرورة التربية الاقتصادية , مظاهر البذخ والإنفاق (في غير موضعين)

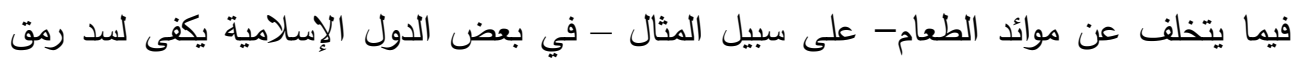

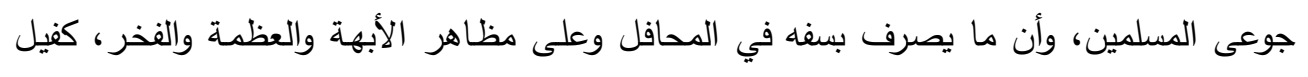
بتحقيق نهضـة تتموية كبرى للقضاء على شبح البطالة خاصـة بطالة المتعلمين الذى يهدد

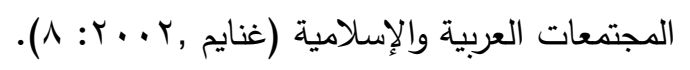

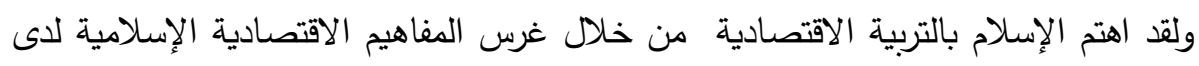

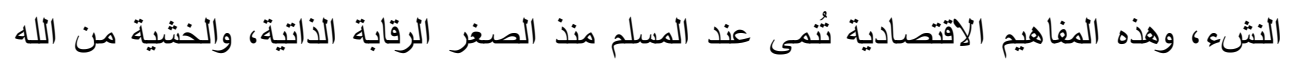

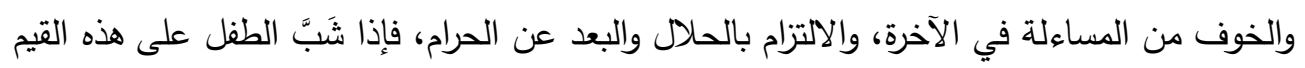

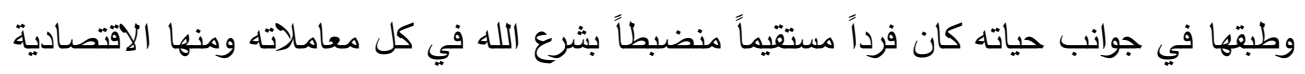

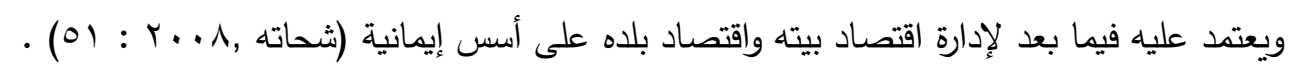

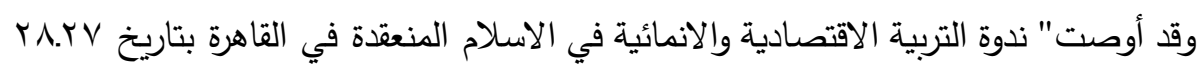
يوليو r . . ץ" بأن يقوم واضعوا المقررات الدراسية بتضمين التربية الاقتصادية في مختلف المراحل

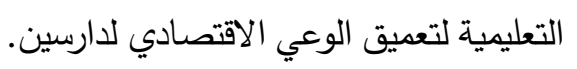
ولكي يتمكن الفرد من مسايرة التغيرات الاقتصادية عليه أن يؤسس علاقاته على عادات لاتصنين

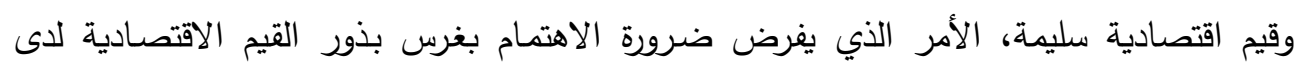

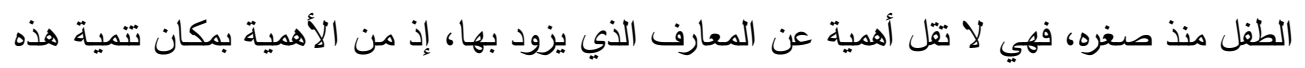

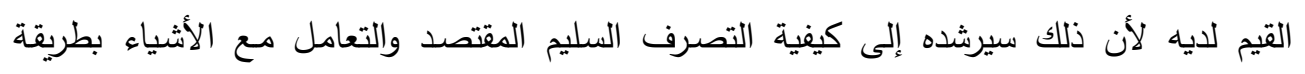

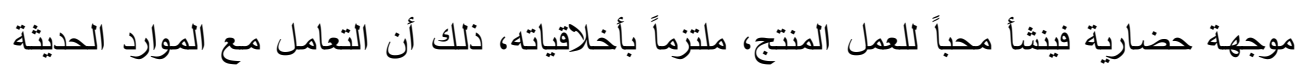

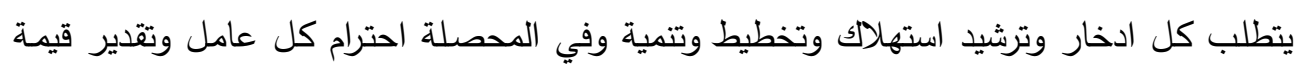

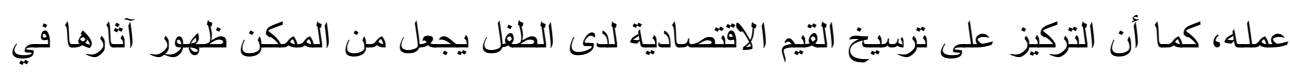

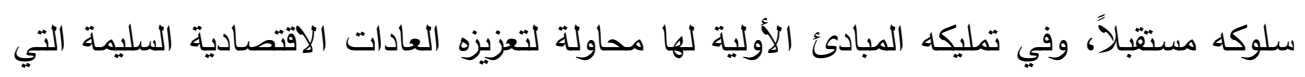

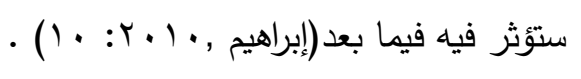


ومما سبق يتضح أن لمؤسسات رياض الأطفال أهمية تربوية في تتمية ميول واتجاهات الطفل في سن مبكر , وتتشئته تتشئة اجتماعية سليمه , وتكوين شخصيته السليمة وإكسابه القيم والدفاهيم التي تساعده وتتطورفي حياته, وللتربية الاقتصادية دور مهم في نشر الثقافة الاقتصادية

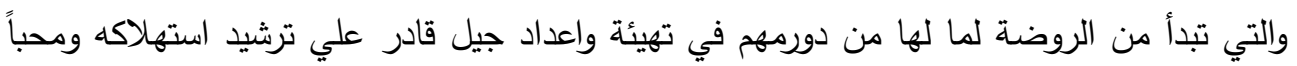
للعمل المنتج , وتعزيز العادات والسلوكيات الاقتصادية السليمة التي ستؤثر علي الطفل فيما بعد. مشكلة الدر اسة :

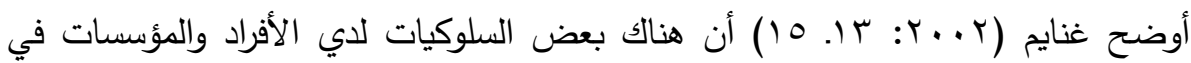
مصر تدعم وتثجع العادات الاستهلاكية المعوقة للإنتاج , وتظهر قلة الوعي الاقتصادي والتربية الاقتصادية ,ومما يؤكد ذلك بعض الحالات والمواقف من الواقع الاجتماعي منها :

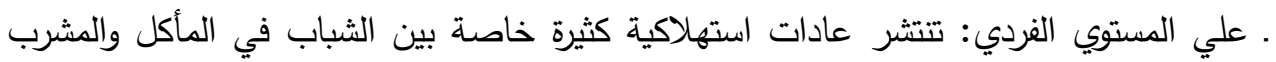

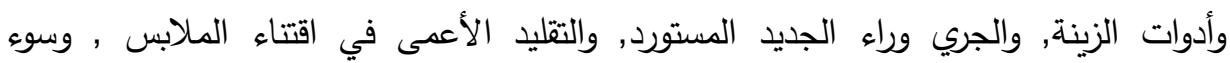

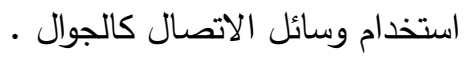
• علي المستوي الأسري: هناك أيضاً مظاهر عديدة للإنفاق في غيرموضعه الصحيح والإسراف

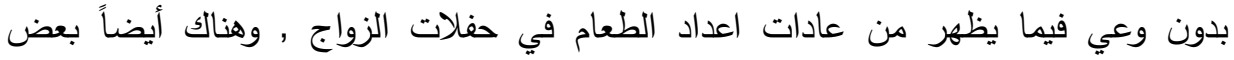

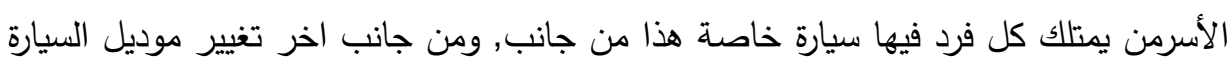

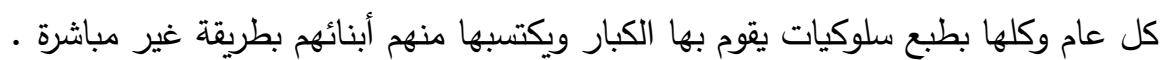
. علي المستوي الحكومي: هناك الكثير من المواقف التي تعكس الحاجة إلي تربية اقتصادية ,

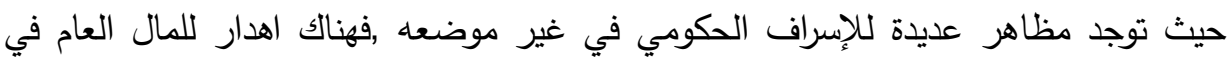
كثير من المواقف والحالات,مثل المبالغة في المواكب الحكومية والسيارات الفارهة والانتخابات والاستفتاءات المختلفة , وما يترتب عليها من إنفاق الملايين , وضياع وقت العاملين وتعطيل

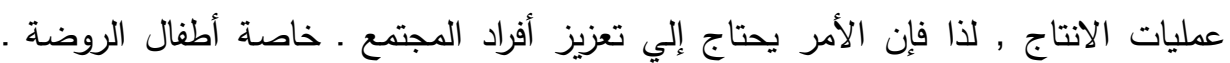

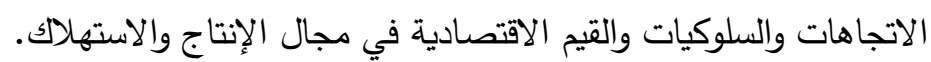

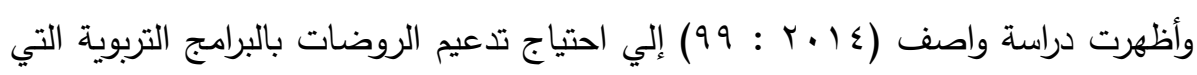

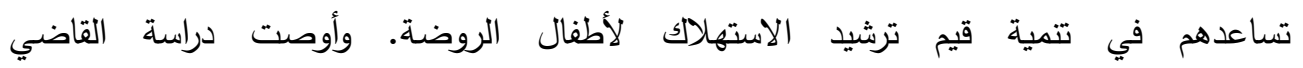

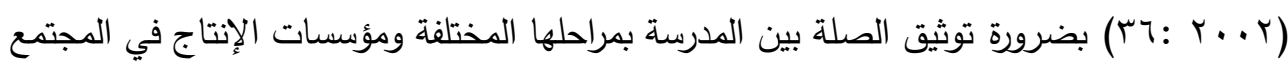

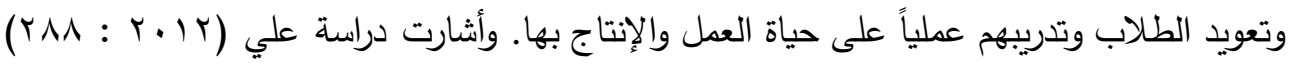

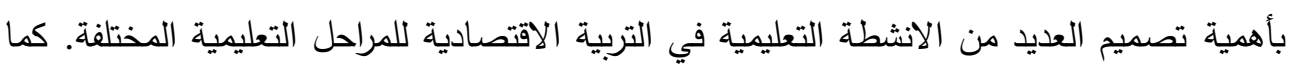




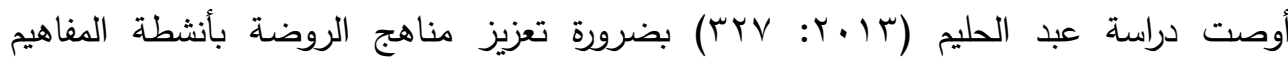

الاقتصادية , التي تتميز بمحاكاتها لمواقف اقتصادية يمر بها الطفل في الحياة اليومية .

ومن هذه المؤشرات السابقة يتضح ضعف اهتمام مؤسسات رياض الأطفال بتحقيق التربية

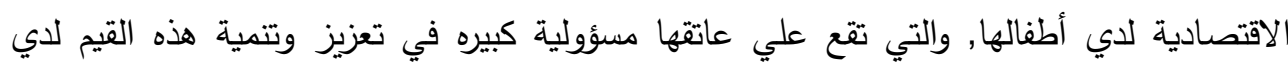

أطفال الروضة, وتتشئتهم تتشئة تتقق مع قيم مجتمعهم.

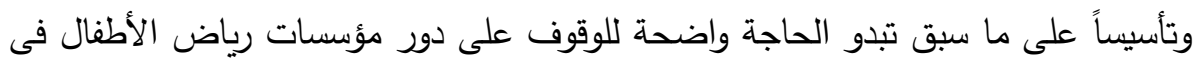

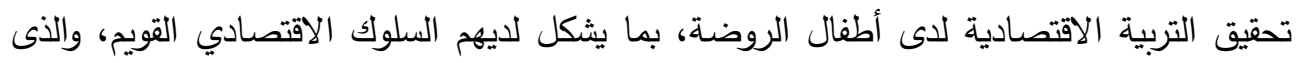

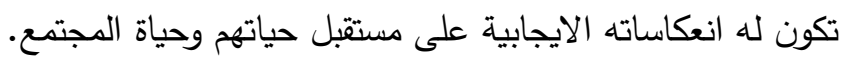
وعليه تتحدد مشكلة البحث في السؤال الرئيسي التالي :

ما واقع تحقيق التربية الاقتصادية لاي أطفال الروضة بمحافظة الدقهلية ؟ ويتفرع من السؤال الرئيسي السؤلين التاليين:.

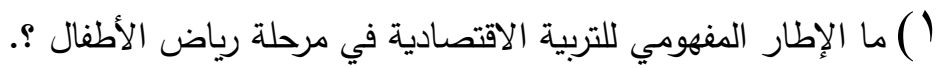

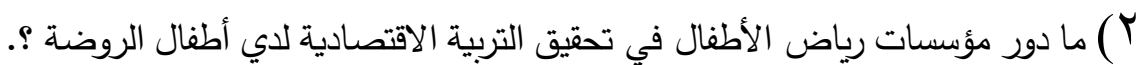

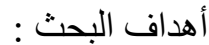

يتمثل الهدف الرئيسي في البحث الحالي في الوقوف واقع تحقيق التربية الاقتصادية للي أطفال الروضة , ويتفرع من الهدف الرئيسي الأهداف الآتية :.

ا. تحديد الإطار المفهومي للتربية الاقتصادية في مرحلة رياض الأطفال .

ז. الكثف عن دور مؤسسات رياض الأطفال في تحقيق التربية الاقتصادية لدي أطفال الروضة.

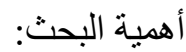

تتحدد أهمية البحث من الجوانب التالية :.

1-أهمية مؤسسات رياض الأطفال في تأهيل الطفل علمياً واجتماعياً ونفسياً واستكثاف قدراته

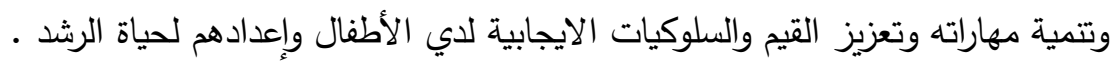

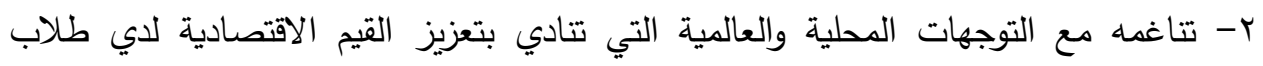
مراحل التعليم المختلفة كأساس لبناء شخصية الطالب القادر علي العمل والانتاج وربما

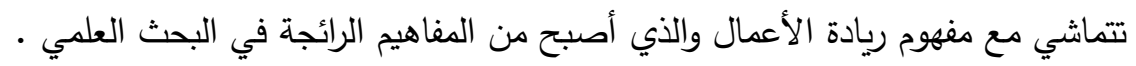

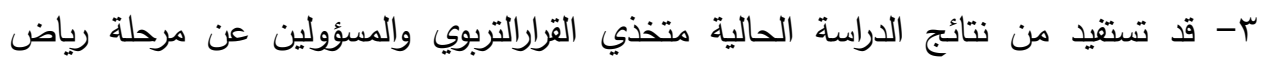
الأطفال في التعرف علي أدوار مؤسسات رياض الأطفال في تحقيق التربية الاقتصادية 
والمعوقات التي تحول دون تحقيق ذلك، بما يمكنه من اتخاذ المبادرات والقرارات الكفيلة

$$
\text { مجنمع وعينة البحث : التربية الاقتصادية لدي أطفال الروضة . }
$$

يتمثل مجتمع البحث الحالي في معلمات رياض الأطفال الحكومية بمحافظة الدقهلية والبالغ

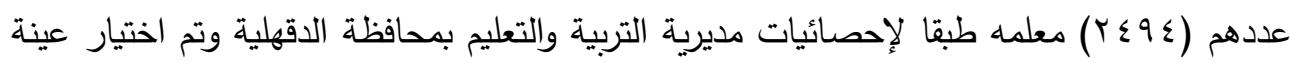

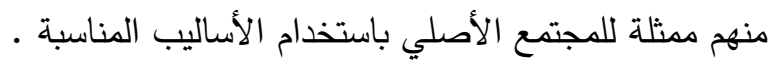

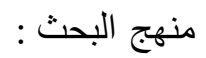

وفقا لطبيعة البحث الحالي ، وما تقضيه الإجابة عن تساؤلاته ، وتحقيق أهدافه ، يستخدم

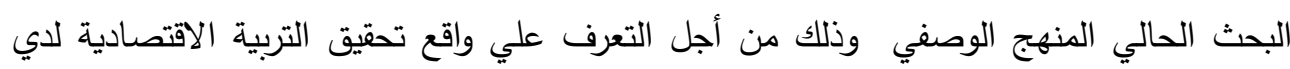

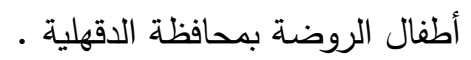
أدوات البحث :

تحقيقاً لغاية البحث وللإجابة عن تساؤلاته فيما يتعلق بالثق الميداني فإن الاستبانة هي الأداء الملائمة للبحث الحالي وذلك بهدف التعرف علي واقع تحقيق التربية الاقتصادية لدي أطفال

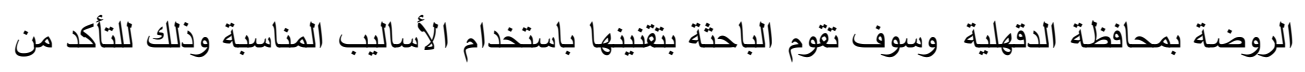
مصداقيتها وصلاحيتها للتطبيق.

$$
\text { تتمثل مصطلحات البحث : }
$$

\section{Kindergarten institutions : مؤسسات رياض الأطفال :}

تعرف رياض الأطفال بأنها: نظام تربوي يحقق التتمية الثاملة للأطفال ما قبل حلقة التعليم

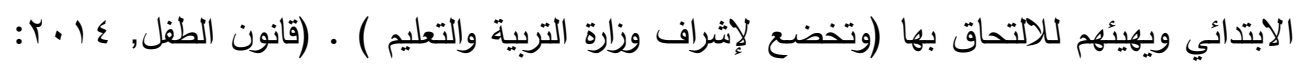

ويتضح مما سبق أن مؤسسات رياض الأطفال هي المؤسسة التربوية التي يلتحق بها الطفل من عمر (ع.7) سنوات, وتقدم البرامج والأنشطة المدروسة التي تساعد الطفل علي تحقيق نموه وتتشئته تتشئة تساعده في الاندماج مع مجتمعه , وسوف تتبنى الباحثة تعريف قانون الطفل

$$
\text { كتعريف إجرائي. }
$$




\section{Economic Education التربية الاقتصادية:}

تعرف الباحثة التربية الاقتصادية إجرائيا في البحث الحالي بأنها، التربية التي تتمي لاي التاي

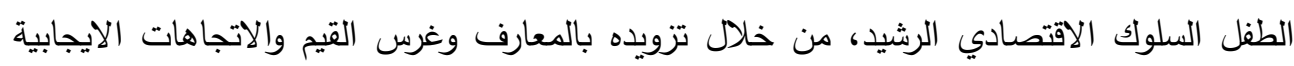

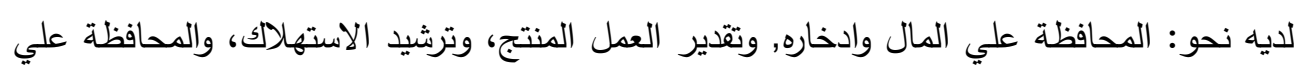

$$
\text { الدراسات السابقة : }
$$

هناك العديد من الدراسات السابقة التي تناولت بعض جوانب تلك الدراسة، وقد استفادت

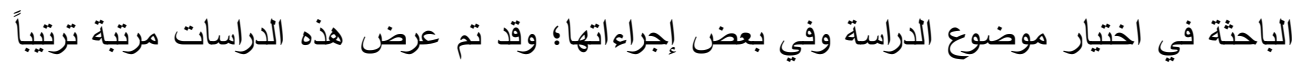

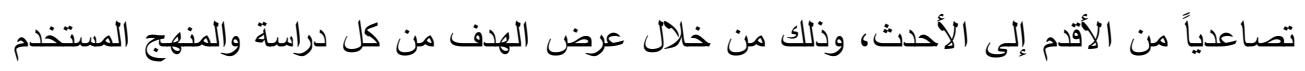

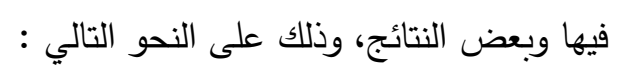

استهدفت دراسة أرمينتو (1983) Armento إلي تحديد المفاهيم الأساسية , والتي يمكن

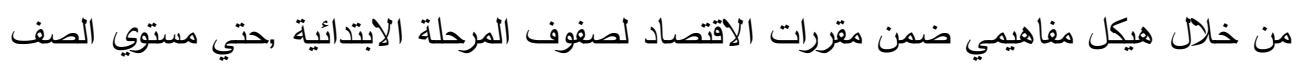

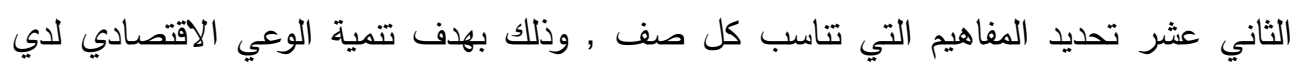

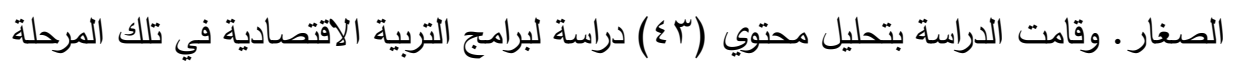

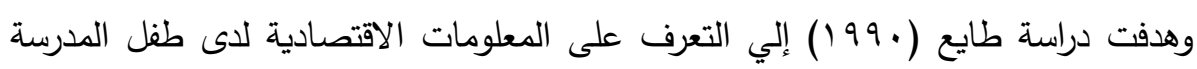

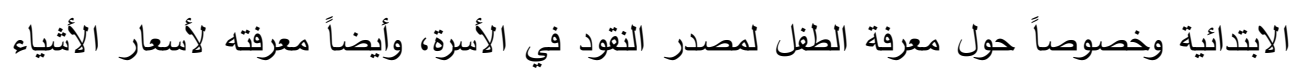

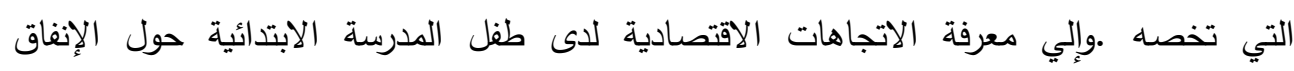

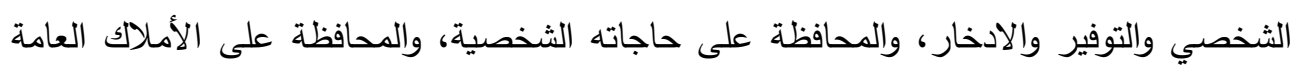

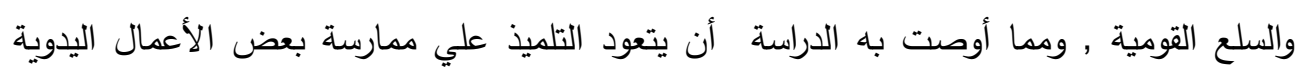

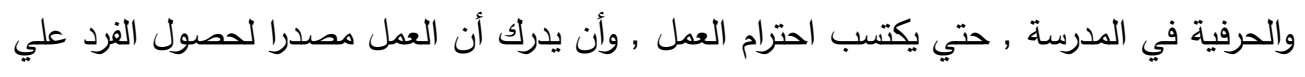

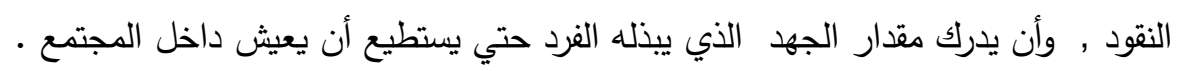

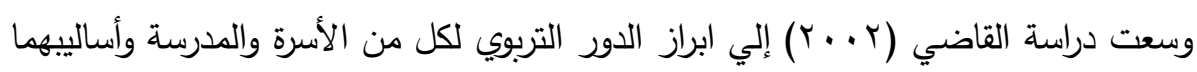

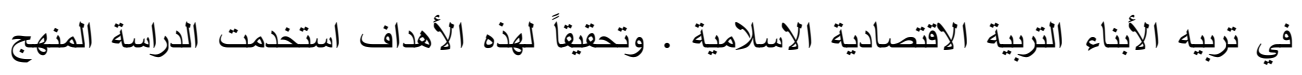

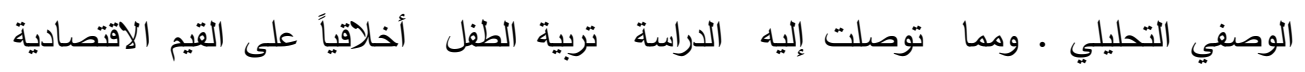

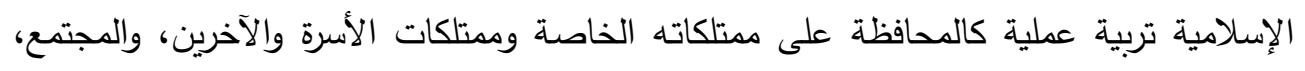

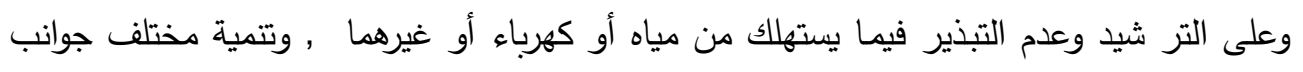


شخصية الطالب بالعلوم والمعارف التي تربيه تربية اقتصادية وإسلامية فينمى دينياً وخلقياً بمعرفة القيم الاقتصادية الإسلامية .

وحاولت دراسة العلياني (9 . . r) إلي التعرف أهم معالم التربية الاقتصادية في القرآن الكريم

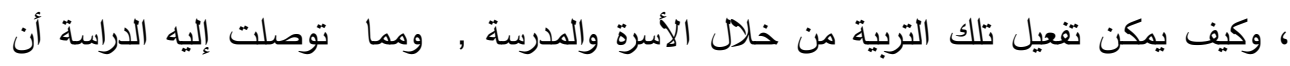

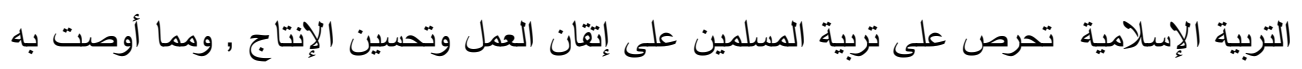

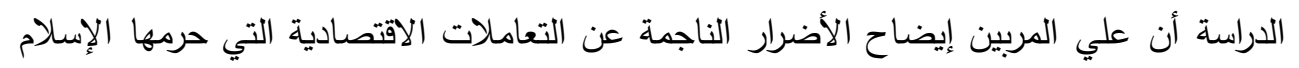
كالربا والاحتكار والغش والسرقة .

وهدفت دراسة محمد (9 . . ب) إلي اعداد تصور مقترح يمكن من خلاله قيام مدارس الحلقة

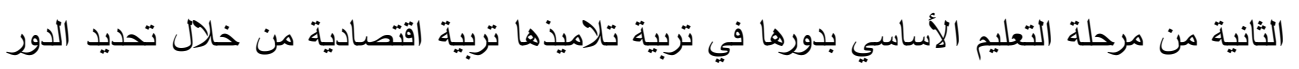

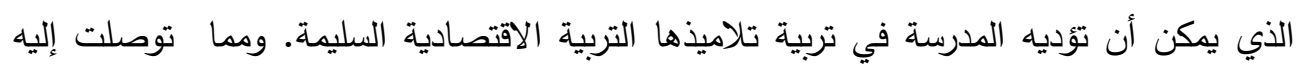

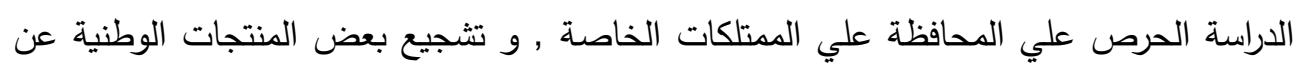

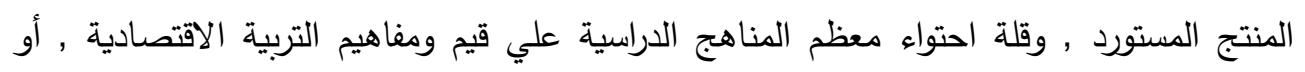

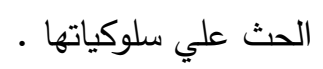

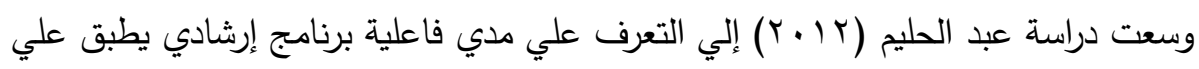

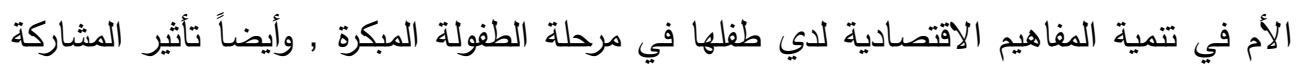

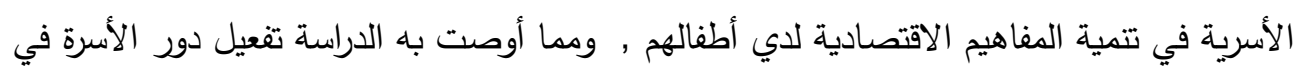
تعزيز أطفالها للمفاهيم الاقتصادية من خلال إشراك الأم في بعض الألنشئ الأنطة التي تمارسها مع طفلها

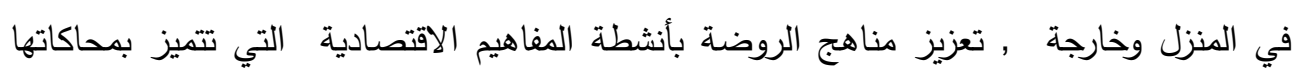

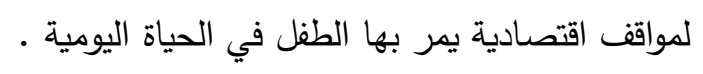

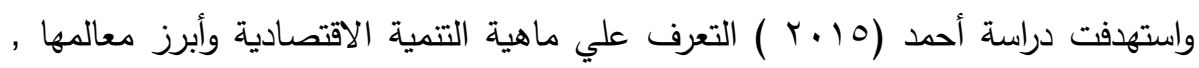

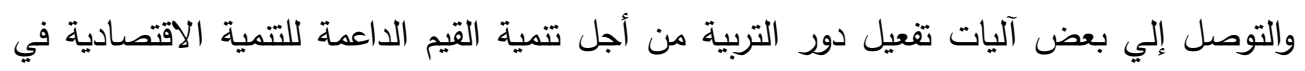

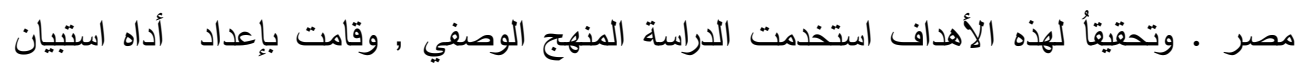

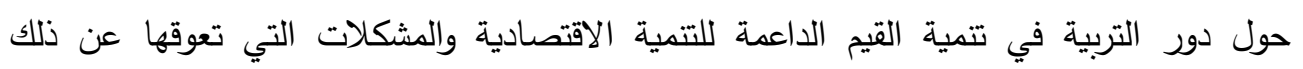
ومقترحات لحلها وطبقت علي عينه من أعضاء هيئة التدريس بكلية التربية في الجامعات. وهدفت دراسة ماياساري Mayasari (2015 إلي معرفة تضدين الاقتصادي النسوي في

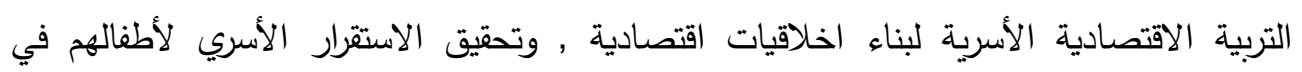

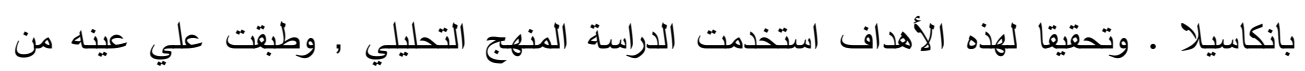


الأمهات ـ وأبرز النتائج التي توصلت اليها الدراسة أن للمرأة دور في تحسين المستوي الاقتصادي للأسرة , وتعليم أطفالها أنماطاً ومواقف مختلفة , وأنها أسهمت في تطوير بنية الأطفال المعرفية

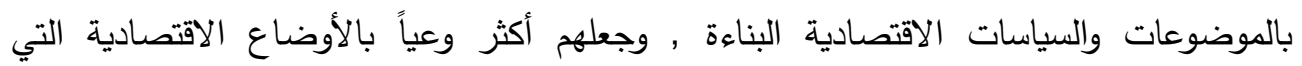
يعيثونها سواء داخل الأسرة أو في مجتمعهم.

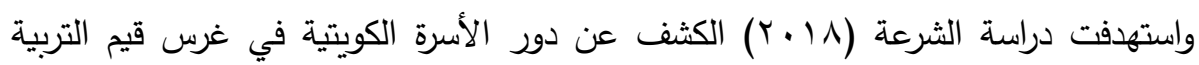
الاقتصادية الاسلامية لاي الأبناء من وجهة نظرهم وعلاقة ذلك بمستوي تعليم الوالدين وقطاع

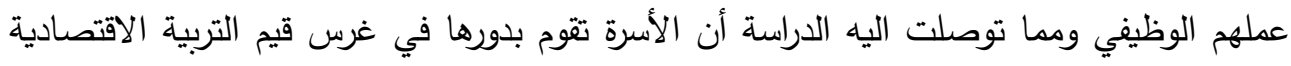

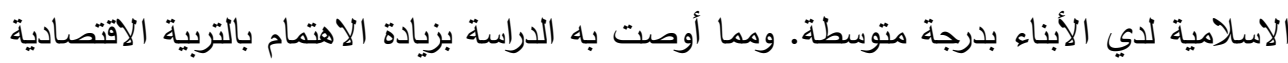

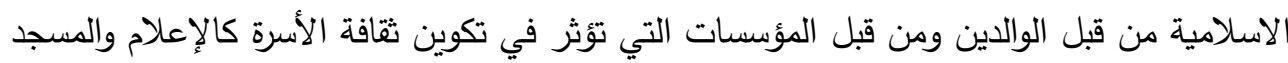
وغيرها , وكذلك التركيز علي سلوكيات خاصة مثل الحث علي الانفاق بشكل عام .

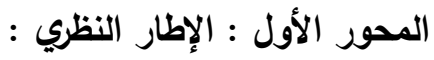

تتضمن الإطار النظري للبحث الجوانب والموضوعات التالية : أولا مفهوم التربية الاقتصادية لا يوجد تعريف متفق عليه لمفهوم التربية الاقتصادية، لتعدد وجهات النظر ومداخل معالجة

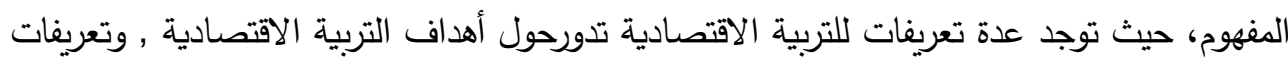
أخرى تركز علي موضوعات للتربية الاقتصادية، ومن هذه التعريفات :

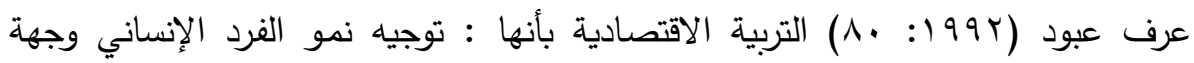
ترتضيها الجماعة ويتعارف عليها الناس ويقرها النظام السائد، في التعامل الاقتصادي للأفراد، خاصة فيما يتعلق بجانبي الإنتاج والاستهلاك بوصفها الركيزة الأساسية للحياة الاقتصادية للأفراد

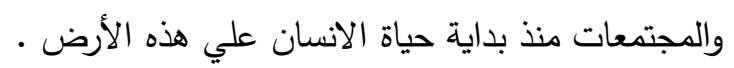

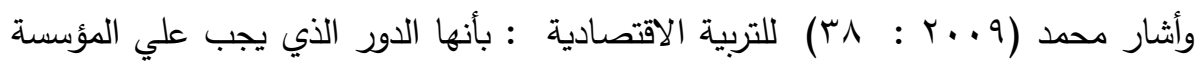
التعليمية القيام به في تتمية وتعديل بعض سلوكيات التلاميذ, التي تتعلق بمتطلبات الحياه الاقتصادية , كغرس قيمة العمل اليدوي وحبه واحترامه من ناحية , وتتمية السلوك الاقتصادي لهيل

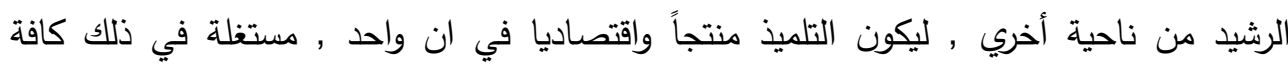
امكاناتها ومقوماتها. و تعرف بأنها : " القدر المناسب من الخبرات الاقتصادية التي تسهم في إعداد المواطن

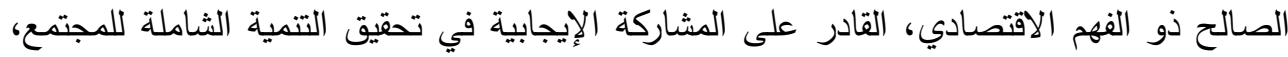




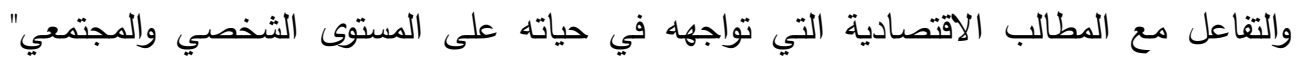
. (علي :Y )

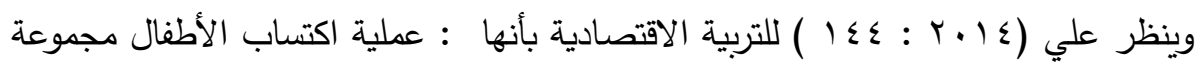
من القيم والمفاهيم والاتجاهات الخاصة بالإنفاق والاستهلاكك والإنتاج و والادخار والتعامل مع البيئة وممتلكاتها وذلك لتوعيتهم وتحقيق التتمية الاقتصادية من خلال الأساليب والوسائل المناسبة .

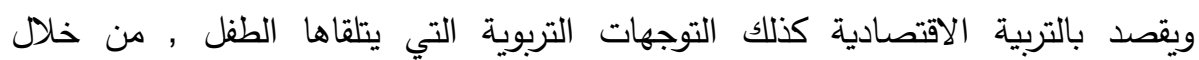
تفاعله مع الوسائط التربوية المختلفة لينظم بها حياته الاقتصادية وفق تعاليم الدين

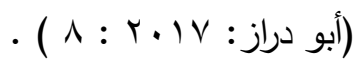
ويشار إليها بأنها : تربية الانسان من خلال كافة المؤسسات وبمختلف الأساليب علي

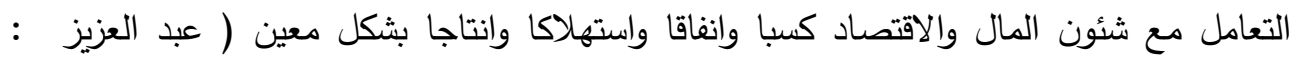
( $)$ ( : : Y . T

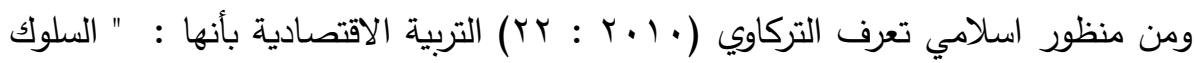
المادي، اليومي للإنسان المسلم في إدارة إمكاناته وموارده المادية، والتعامل مع الجوانب الاقتصادية

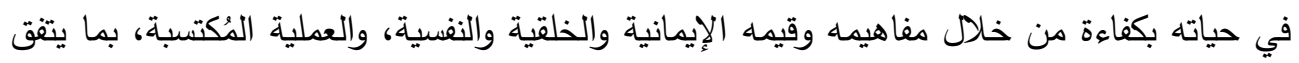

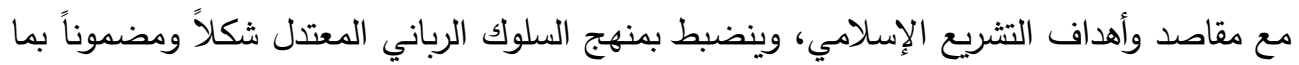
يعود بالنفع على المجتمع والفرد" . ويتضح من التعريفات السابقة للتربية الاقتصادية بأنها عملية اعداد وتوجيه لسلوك الفرد وتتمية وعيه الاقتصادي وتعزيز السلوك الاقتصادي الرشيد لديه ويتطلب ذلك الاهتمام بتتمية جوانب دانب معينه لدي الفرد لتحويله من كائن مستهلك فقط إلي كائن منتج. واستتادا إلي كل ما سبق يتضح إن التربية الاقتصادية تعمل علي :. توجيه نمو الطفل في

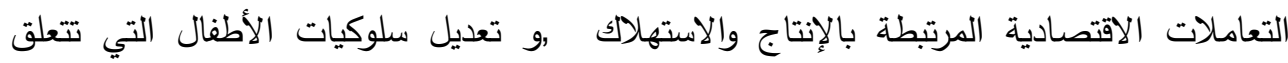

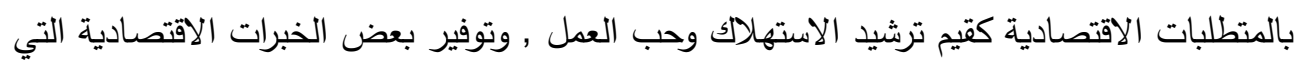

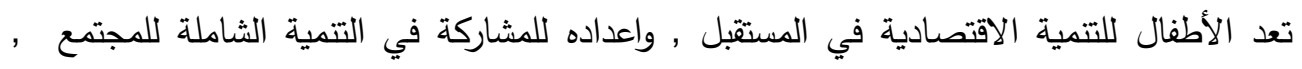

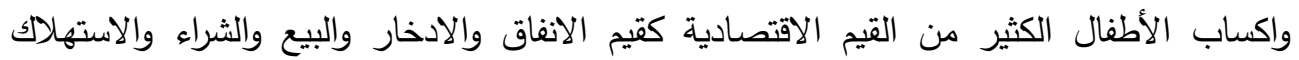

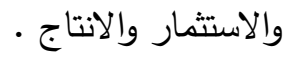
ثانياً : دور مؤسسات رياض الأطفال في تحقيق التربية الاقتصادية لاي أطفال الروضة . 
نظرا لأهمية مؤسسات رياض الأطفال في تحقيق النمو الكامل للطفل , فإن لها دور هام في الكاي تحقيق التربية الاقتصادية لدي أطفال الروضة , حيث تساعد الطفل علي اكتساب السلوكيات الاقتصادية المرغوب فيها كالترشيد والادخار وحب العمل واحترام المهن , وجميع المسئولين في

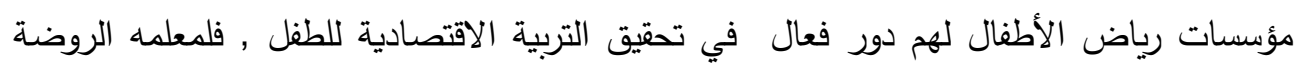

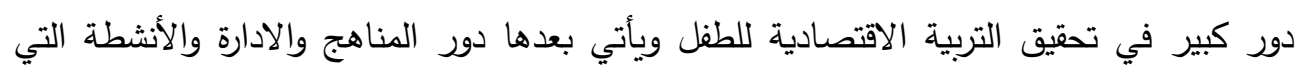
تساعد المعلمة في تحقيق التربية الاقتصادية لطفل الروضة , فلكل منهم دور مهم في اكساب الطفل للتربية الاقتصادية وقميها . تصناعل

وعلي المؤسسات التربوية أن تقوم بدورها في تتمية التربية الاقتصادية وقيمها اللازمة

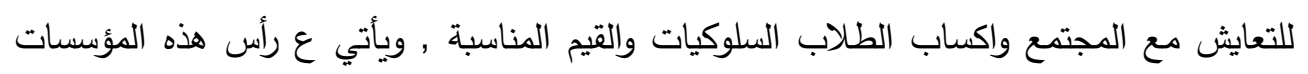

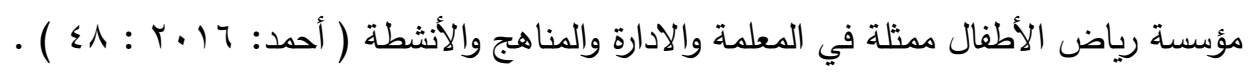

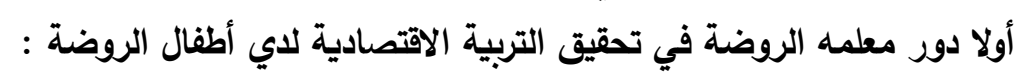

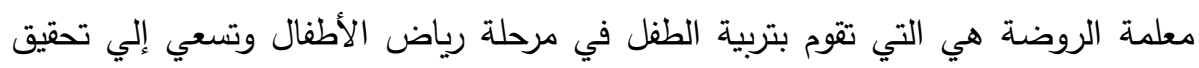

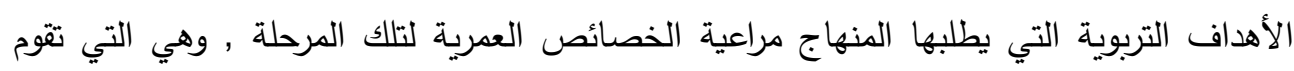

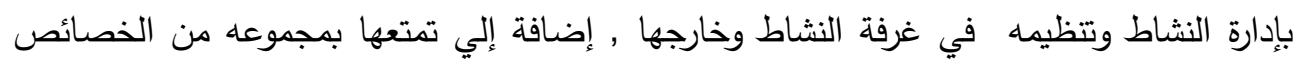
الثخصية والاجتماعية والتربوية التي تميزها عن غيرها من معلمات المراحل العمرية المختلفة

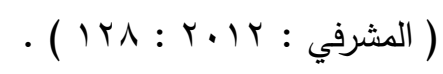

ومن مهام المعلمة التي تساعد بها الطفل في اكتساب التربية الاقتصادية تتمية عادة الادخار لدي الطفل من خلال تشجيعه علي فتح دفاتر التوفير أو عمل حصالات منزليه , وأيضا

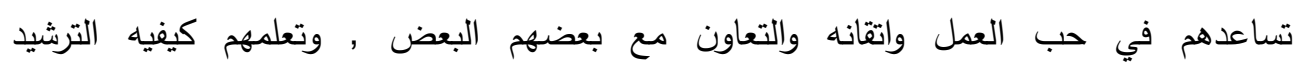

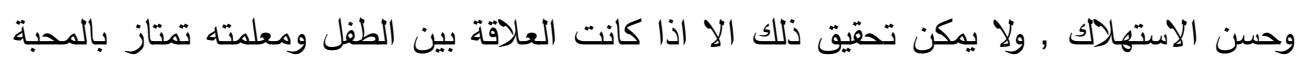

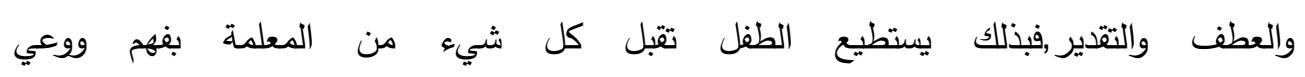

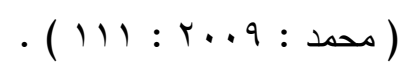

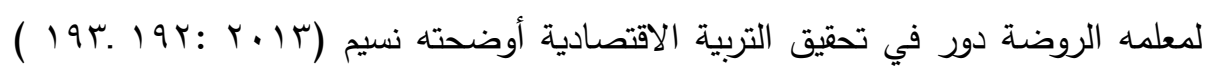

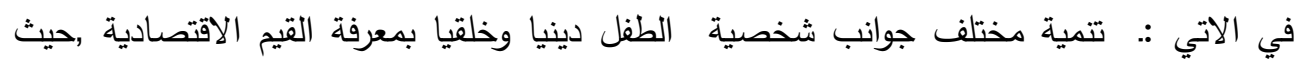

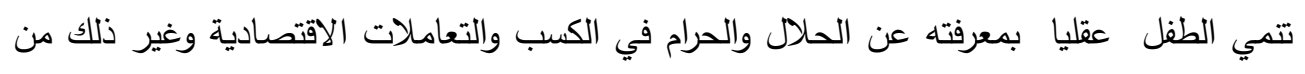
معارف تفيده في تتمية بقية الجوانب الجسمية والاجتماعية والارادية فيما يتعلق بالاقتصاد والتربية الاقتصادية, وتقديم الأنشطة المختلفة والتي تبث من خلالها مفاهيم وسلوكيات التربية الاقتصادية 
وتتبع بحلقة نقاش مع الأطفال لتعزيز السلوكيات الايجابية التي تعلموها من خلال النشاط , و متابعه الأطفال في الحفاظ علي الممتلكات العامة والخاصة داخل وخارج الروضة التعات و توعية الطفل

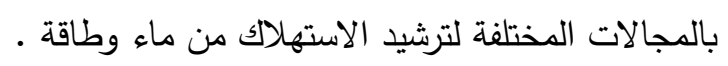

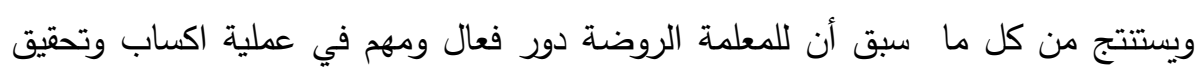

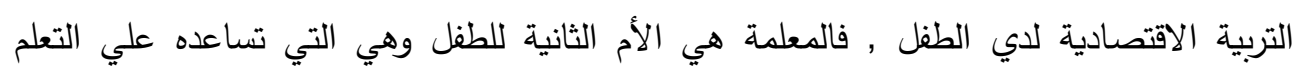

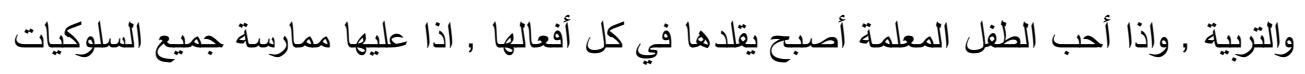

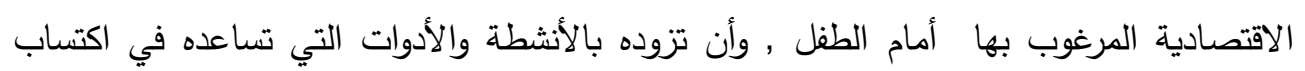

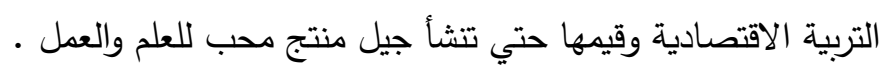

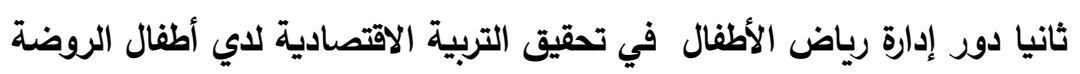

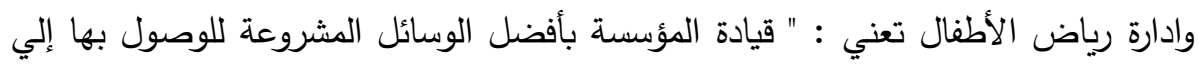

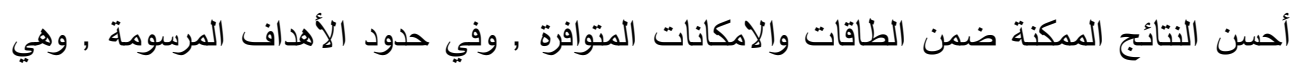
نوع من التظيم الذي يهدف إلي تسيير شؤون المؤسسة بصورة عامه , وإلي تهيئة جميع الظروف

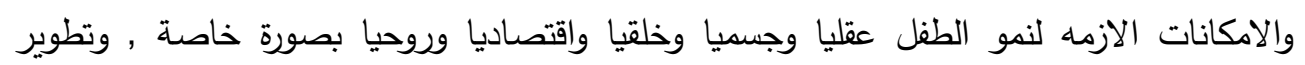

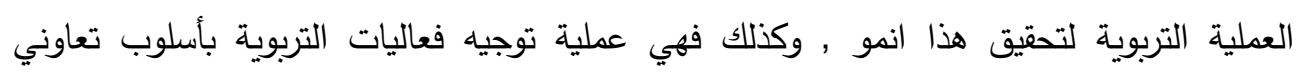

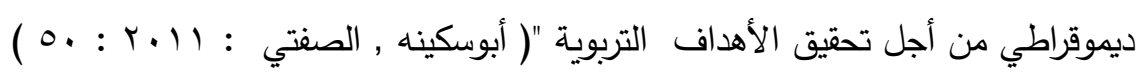

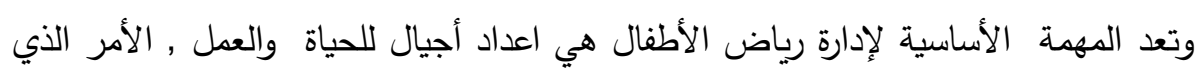

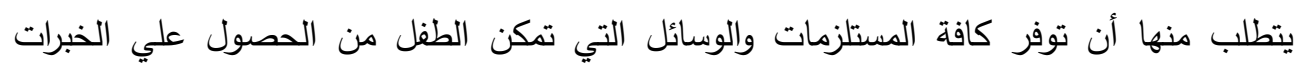

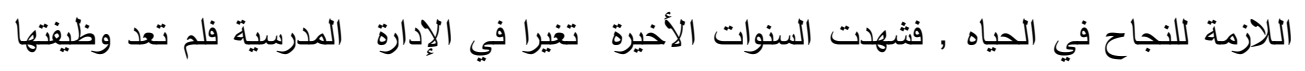

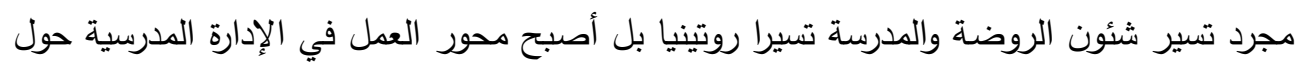

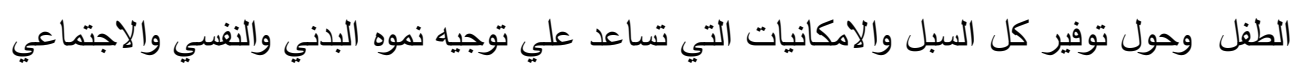

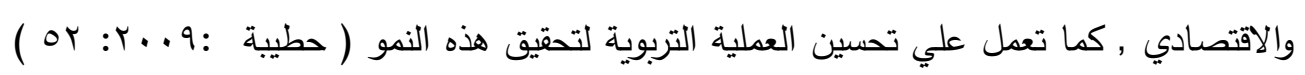

و للإدارة رياض الأطفال دور مهم في تحقيق التربية الاقتصادية من خلال عدة وسائل هي

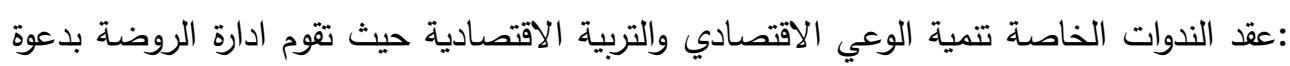

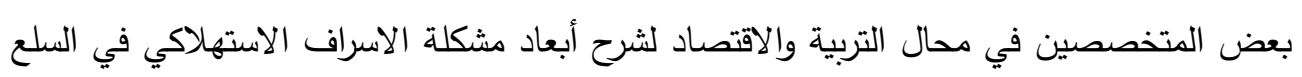
المختلفة علي الفرد والمجتمع , وكيفية العمل علي الحد من هذا الاسراف والتبذير في الاستهلاك

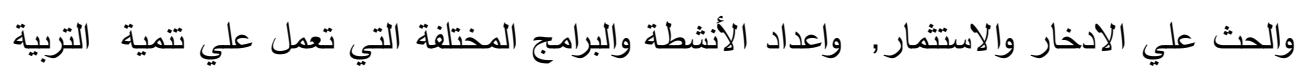


الاقتصادية وقيمها ويتمثل ذلك في قيام ادارة الروضة بتكوين الجماعات للنشاط داخل الروضة

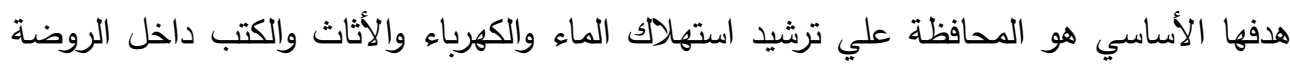

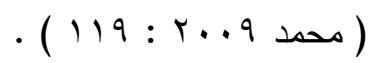

وانطلاقا مما سبق فإن علي ادارة رياض الأطفال بذل الجهود من أجل النهوض بالأهداف

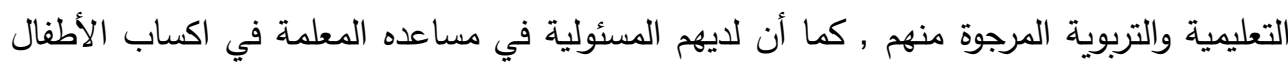
جميع جوانب التربية وخاصة التربية الاقتصادية , وغرس القيم الايجابية والسلوكيات المتعلقة

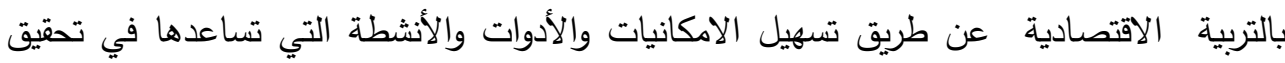
التربية الاقتصادية لاي الأطفال.

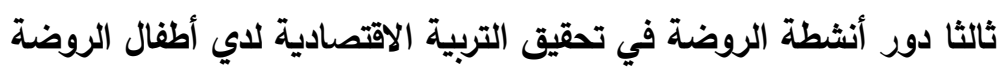

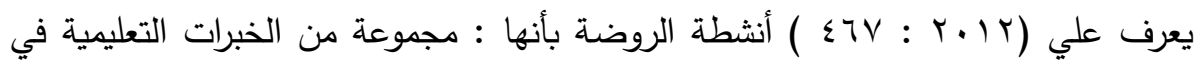
التربية الاقتصادية، يتم تصميمها وتتظيمها في ضوء أهداف واستراتيجيات تدريسية وتقويمية، ويكون

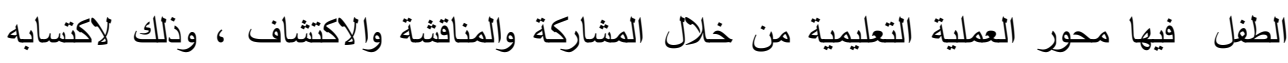
بعض أبعاد التربية الاقتصادية، بهدف التأثير الإيجابي عليه .

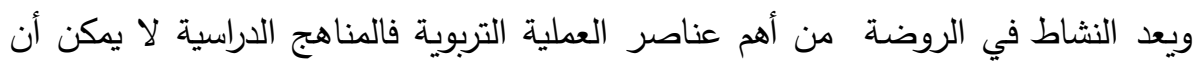

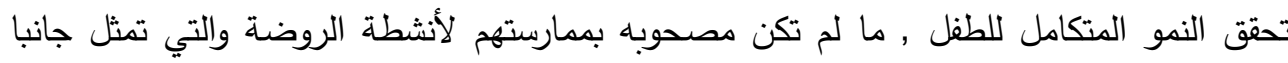
تربويا هاما ومكمل للعملية التعليمية , حيث يصبح التدريس من خلال الأنشطة التعليمية مبسطا , كما أن استخدام الأنشطة في التدريس بصورة مقصودة يساعد الطفل علي اكتساب القيم والسلوكيات بطريقه جاذبة وشيقه ( سليمان : 7 . . ب : 7 ) ) . ولأنشطة الروضة دور مهم في تحقيق التربية الاقتصادية لدي أطفال الروضة فهي تعمل التهل

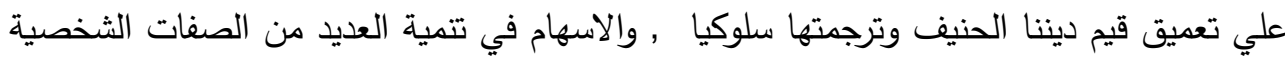

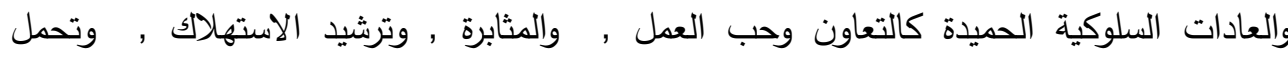
المسئولية , وتقدير قيمة العمل اليدوي والاستمتاع به واحترام العمل والعاملين من خلال الممارسة ولتهية

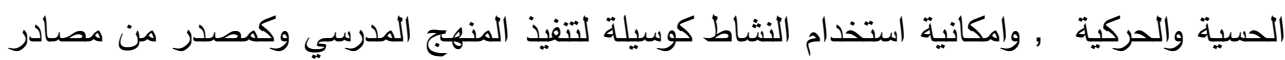

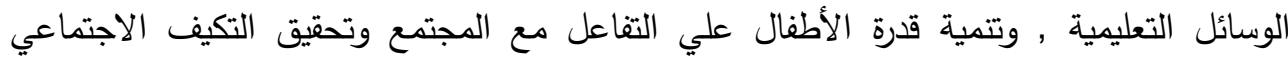
والاقتصادي , والمساعدة علي حسن استخدام أوقات الفراغ بما يعود علي الممارسين بالفائدة , والقدرة

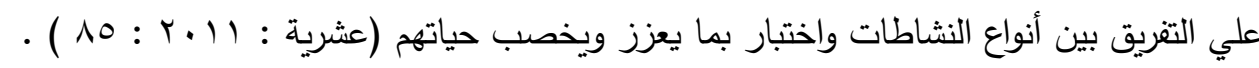


واستتادا علي ما سبق فإن لأنشطة الروضة دور في تحقيق التربية الاقتصادية وتتمية الوعي

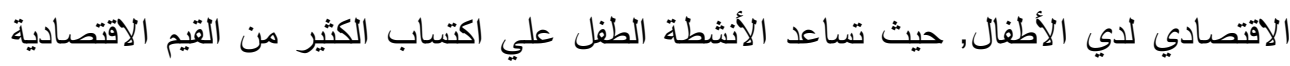

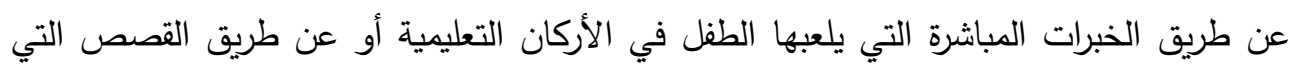

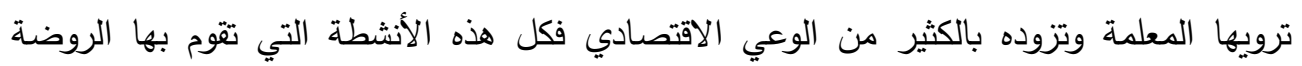
تساعده علي تحقيق التربية الاقتصادية وكيفية جعله طفل اقتصادي غير استهلاكي.

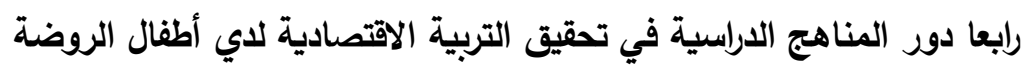

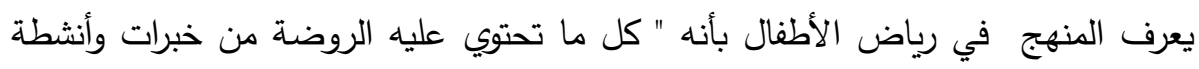

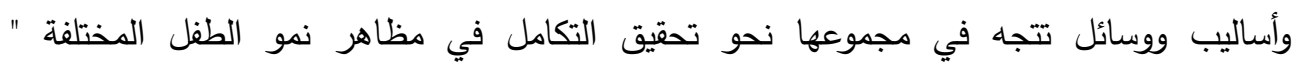

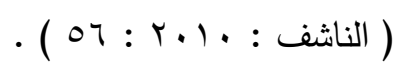
وتعد المناهج الدراسية التي يدرسها الطفل أداة لتثكيل عقله ومعارفه واتجاهاته , لذلك فان المناهج الدراسية لابد أن تراعي خصائصه ومظاهر نموه , وتمثل المناهج الدراسية أهم المقومات

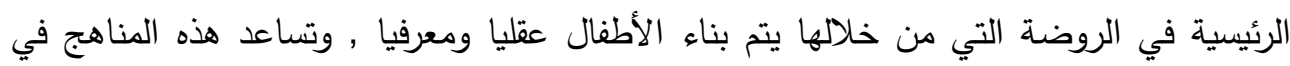
تحقيق الأهداف التي يريدها المجتمع , وأن تساعد علي اكساب الطفل قيم المحافظة علي المال العام , وترشيد الاستهلاك واكتساب عادات الادخار والاستثمار , ولكي يتحقق هذا يجب دهاع مراعاة

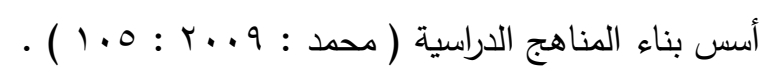

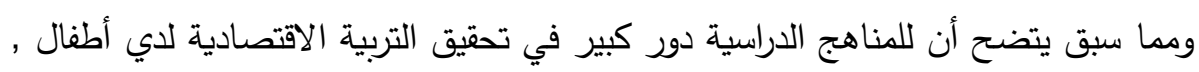

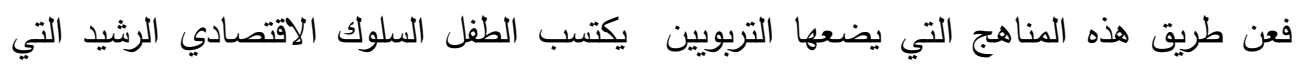

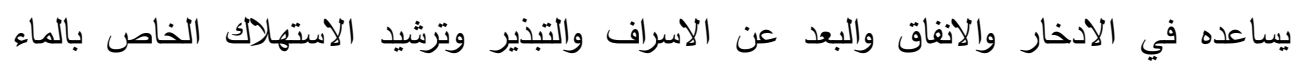

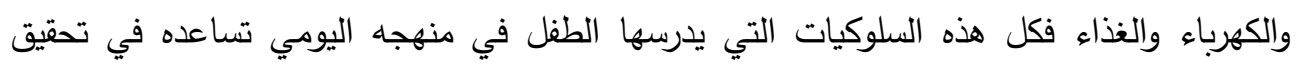
التربية الاقتصادية لدية . المحور الثاني : البحث الميداني : يتتاول هذا المحور أهداف البحث الميداني , وعينته , وأداته , والنتائج , وتفسيرها كما يلي : أولاً : أهداف البحث الميداني تمثلت أهداف الدراسة الميدانية في تحديد واقع دور مؤسسات رياض الأطفال في تحقيق

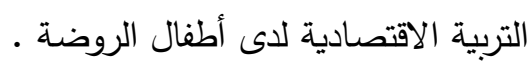
ثانياً: عينة البحث الته 
تمثل مجتمع البحث في معلمات رياض الأطفال بحافظة الدقهلية , وتم سحب عينة

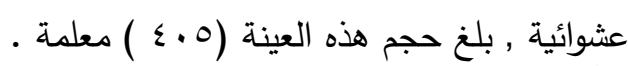
ثالثًا : أداة البحث ( الاستخ حمثنة

اعتمد البحث علي الاستبانة في مسعي لتحقيق أهدافه الميدانية , المتمثلة في التعرف علي

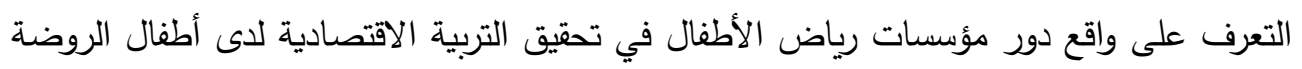
وقد اشتملت الاستبانة علي ، •ـ عبارة وتتضمن هذه العبارات أربعة أبعاد هي :

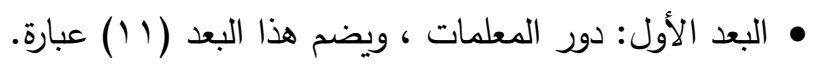
• البعد الثاني: دور إدارة رياض الأطفال ، ويضم هذا البعد (• (1) عبارة.

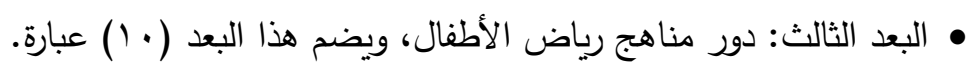

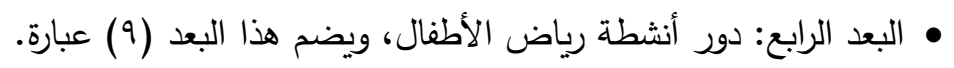

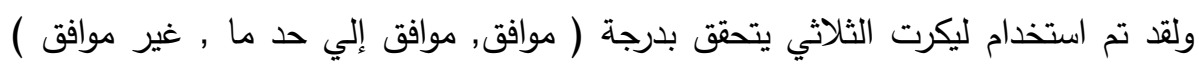
لتحديد درجة موافقة أفراد العينة . رابعًا : إجراءات تقنين الاستبانة : اعتمدت الباحثة للتحقق من صدق أداة البحث علي طريقتين هما :

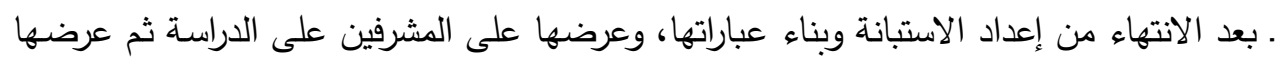

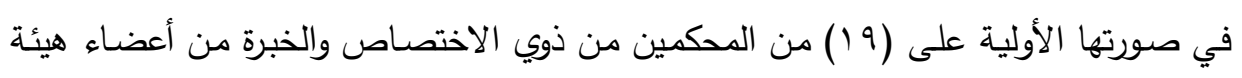
التدريس بجامعة المنصورة، وعدد من الجامعات المصرية الأخرى.

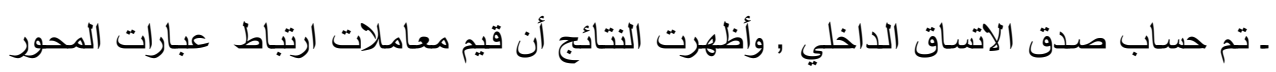

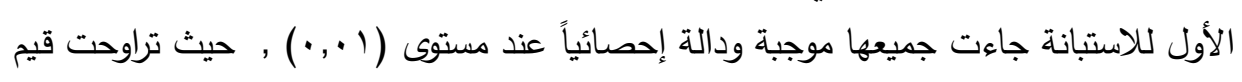

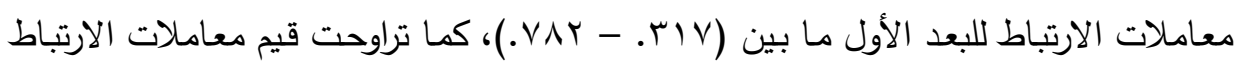

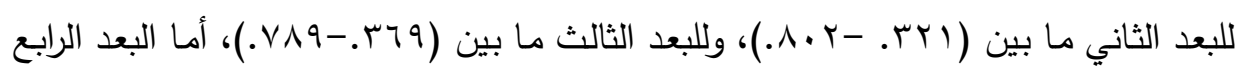

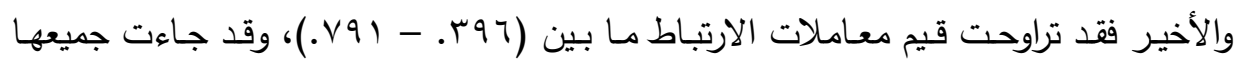

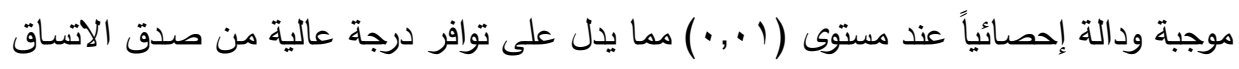
الداخلي بين كافة عبارات أبعاد المحور الأول . خامسًا : نتائج البحث الميداني : 
تم ترتيب أبعاد واقع دور مؤسسات رياض الأطفال في تحقيق التربية الاقتصادية لدى أطفال

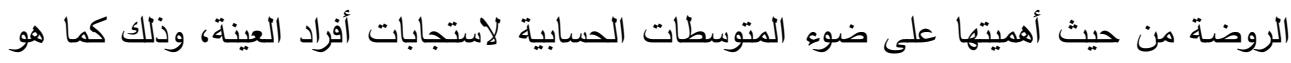
موضح بجدول (l) التالي:

\section{جدول(1)}

المتوسطات الحسابية والانحرافات المعيارية لاستجابات أفراد العينة حول واقع دور مؤسسات رياض الأطفال في تحقيق التربية الاقتصادية لاى أطفال الروضة مرتبة تنازلياً

\begin{tabular}{|c|c|c|c|c|c|c|}
\hline الموافقة & ترتيب & الانعراف & المستوسطي المسب & البعد & المحور & م \\
\hline موافق & $r$ & .411 & 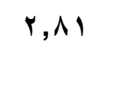 & رياض الأطفال & \multirow{4}{*}{ الألقال دور مؤسسات رياض الحقيق التربية } & 1 \\
\hline موافق & $\varepsilon$ & . & $r, \Lambda$. & دور إدارة رياض & & $r$ \\
\hline موافق & 1 & $.11 \varepsilon$ & r,q. & رياض الأطفال & & $r$ \\
\hline موافق & r & .110 & $\uparrow, \wedge \wedge$ & رياض الأطفال & & $\varepsilon$ \\
\hline موافق & - & $.1 \mathrm{VV}$ & Y,AD & & المتوسط العام & \\
\hline
\end{tabular}

ومن جدول(1) السابق يتضح اتفاق أفراد العينة على "واقع دور مؤسسات رياض الأطفال

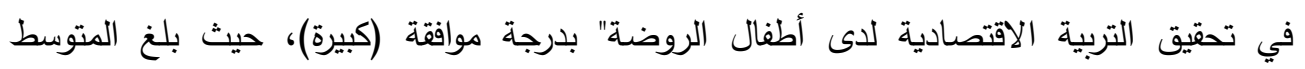

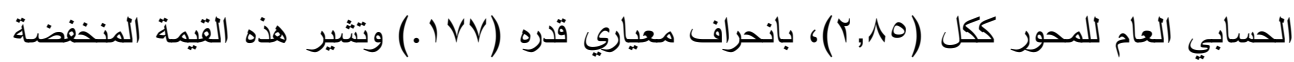
من الانحراف المعياري إلى درجة عالية من الاتفاق بين غالبية أفراد العينة على هذه الأبعاد.

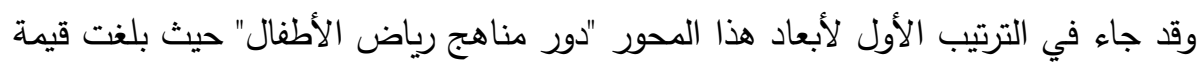

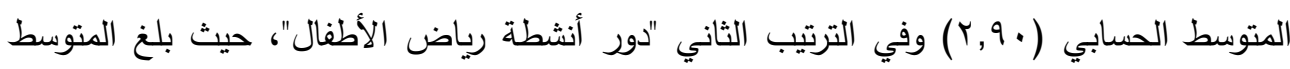

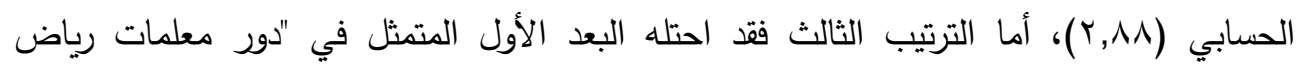

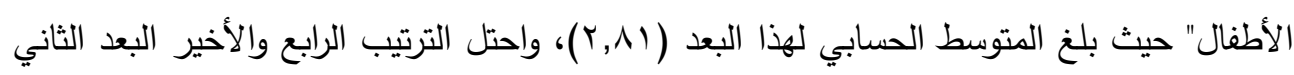

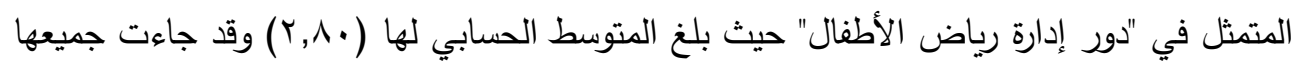

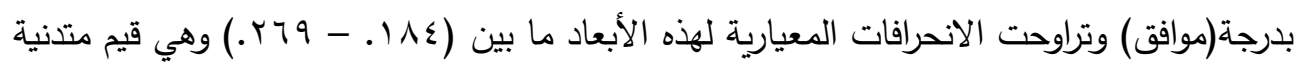
مما يدل على تجانس استجابات أفراد العينة حول أبعاد محور "واقع دور مؤسسات رياض الإداد الأطفال 
في تحقيق التربية الاقتصادية لدى أطفال الروضة" و يفسر احتلال مناهج رياض الأطفال للترتيب الأول إلى أهمية المرحلة و تأثيرها فى تكوين شخصية الطفل ، حيث أنها تتكون من قيم و مفاهيم و

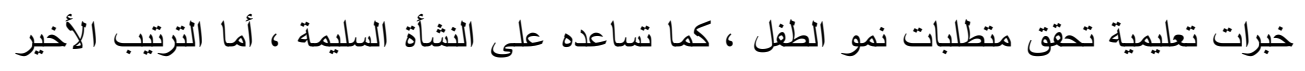

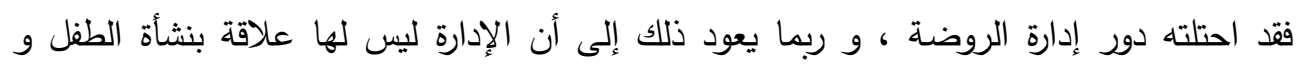

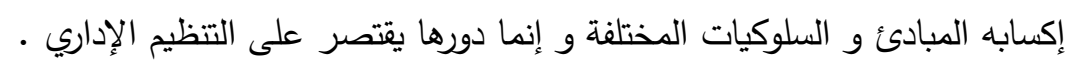

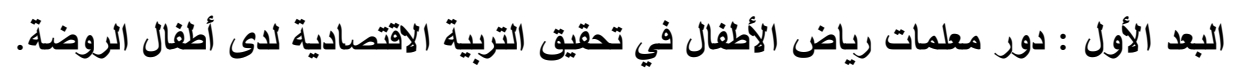

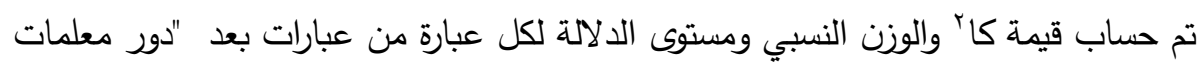

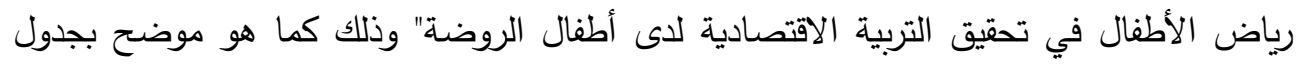

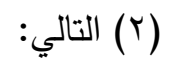

جدول (r)

قيمة كا؟ والترتيب لاستجابات أفراد العينة حول بعد دور معلمات رياض الأطفال في تحقيق التربية الاقتصادية لاى أطفال الروضة مرتبة ترتيباً تنازليا

\begin{tabular}{|c|c|c|c|c|c|c|c|c|c|c|}
\hline \multirow[t]{4}{*}{ sis } & \multirow[t]{4}{*}{ الترتيب } & \multirow{4}{*}{ النسبي } & \multicolumn{6}{|c|}{ الاستجابات (ن=0 • ؛ ) } & \multirow[t]{4}{*}{ العبارات } & \multirow[t]{4}{*}{ م } \\
\hline & & & \multicolumn{6}{|c|}{ درجة الموافقة } & & \\
\hline & & & \multicolumn{2}{|c|}{ غير موافق } & \multicolumn{2}{|c|}{ موافق إلى حد ما } & \multicolumn{2}{|c|}{ موافق } & & \\
\hline & & & $\%$ & 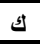 & $\%$ & 5 & $\%$ & s & & \\
\hline **ץ। & $\varepsilon$ & $r, q \leq$ & . & - & 0,9 & $r \varepsilon$ & $9 \leqslant, 1$ & rA & 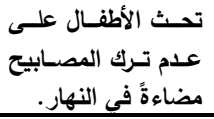 & 1 \\
\hline$* * \leqslant 40,0 Y 4$ & $\wedge$ & $r, \Lambda Y$ & $\cdot, r$ & 1 & 18,1 & $\checkmark \wedge$ & $\wedge r$ & דצr & 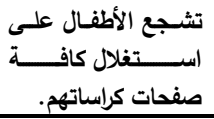 & r \\
\hline$* * \uparrow \wedge q, 10 \wedge$ & 1 & r, १৭ & - & - & 1 & $\varepsilon$ & 99 & $\varepsilon+1$ & 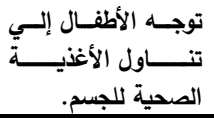 & $r$ \\
\hline **VIV,Ylo & $r$ & $r, q 0$ & $\cdot, \mathrm{v}$ & $r$ & $r, r$ & 14 & 94 & rیq & 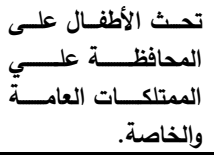 & $\varepsilon$ \\
\hline
\end{tabular}




\begin{tabular}{|c|c|c|c|c|c|c|c|c|c|c|}
\hline ***YY & 1. & $\uparrow, \uparrow$ & $\varepsilon, V$ & 19 & $r \cdot, l$ & Irr & $r 0, r$ & צ & 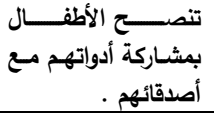 & 0 \\
\hline$* * \vee r \varepsilon, I \vee \wedge$ & r & Y,94 & $\cdot, 0$ & r & $r, v$ & 11 & $94, \wedge$ & rar & تعطي الأطفال أمثلة & 7 \\
\hline **** & عُم & $r, q \leqslant$ & $\cdot, r$ & 1 & $\varepsilon, V$ & 19 & 90,1 & ro & 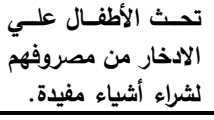 & $v$ \\
\hline **FYY, & ام & $\uparrow, \uparrow$. & $r, V$ & 11 & $r \leq, 1$ & $1 \mathrm{NA}$ & r & rot & تعل تعل الحيوانـات التـي & $\wedge$ \\
\hline$* * \varepsilon<\leqslant, \cdot 10$ & 9 & $r, \vee q$ & 1 & $\varepsilon$ & 11,0 & vo & $\Lambda_{0}, 0$ & YT & تلطلف الأطفال بأعمال & 9 \\
\hline$* * \Delta ৭ ৭, \leqslant \diamond १$ & 7 & $\curlyvee, \wedge q$ & 1 & $\varepsilon$ & $\Lambda, \uparrow$ & ro & $q_{\cdot,, \varepsilon}$ & צו & 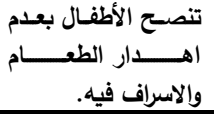 & 1. \\
\hline$* * \circ \vee \wedge, I \vee \wedge$ & $\mathrm{v}$ & $\ulcorner, \wedge \wedge$ & $\cdot, 0$ & r & $1 \cdot, 1$ & \&1 & $\wedge q, \varepsilon$ & ra & 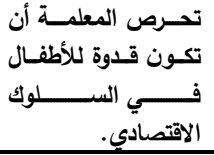 & 11 \\
\hline
\end{tabular}

ومن جدول (Y) السابق يتضح وجود فروق ذات دلالة إحصائية عند مستوى (1 .,. ·) بين

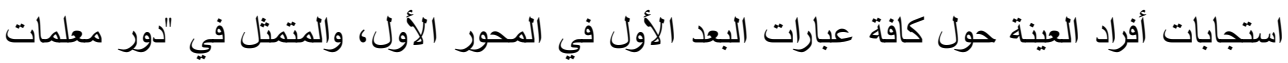

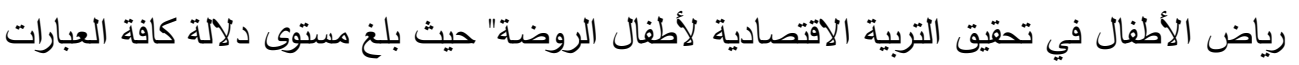

$$
\text { ( ( . .)، وقد جاءت هذه الفروق لصالح الاستجابات (موافق) . }
$$

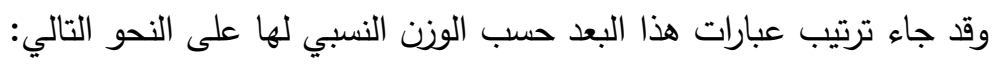

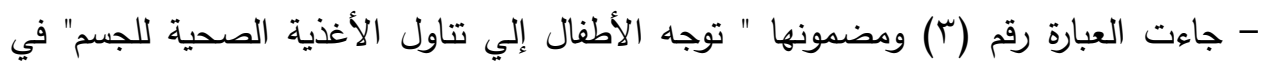

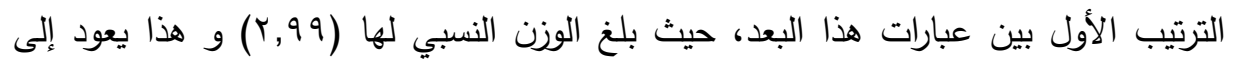

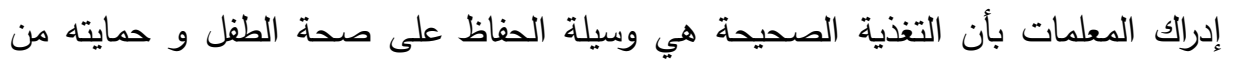

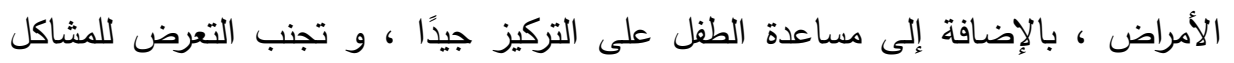

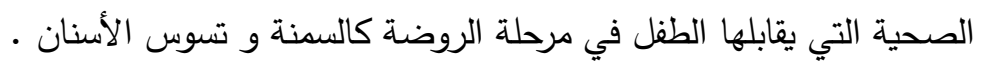

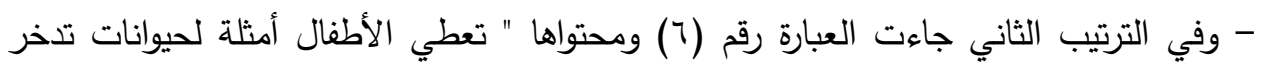

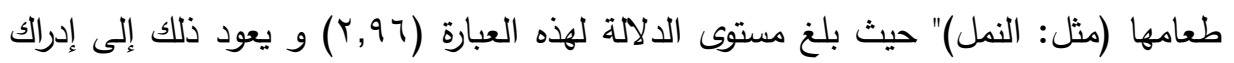

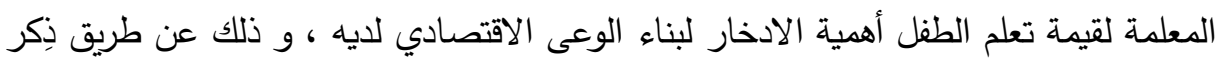


بعض الأمثلة كحياة إحدى الحيوانات المعروفة و التي يتعلم منها قيمة الادخار سواء في

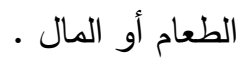

- أما الترتيب الأخير فقد احتلته العبارتين (0، ^) ومضمونهما " تتصح الأطفال بمشاركة أدواتهم

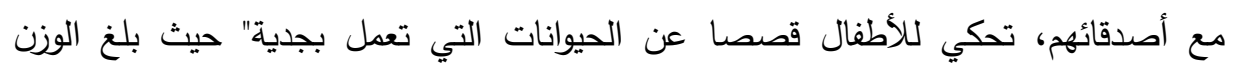

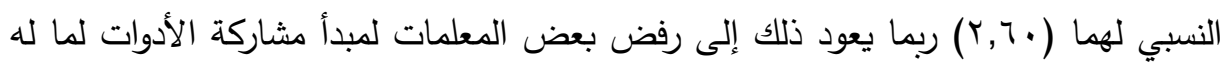

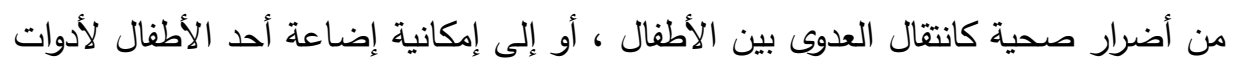

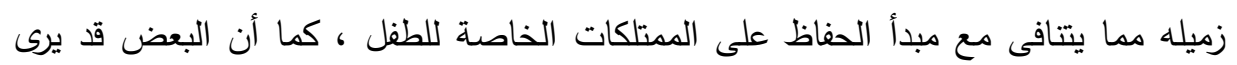

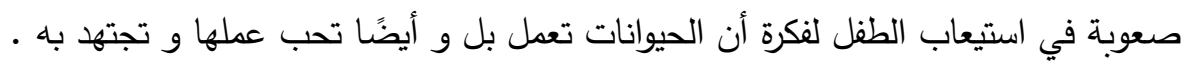

البعد الثاني: دور إدارة رياض الأطفال في تحقيق التربية الاقتصادية لاى أطفال الروضة.

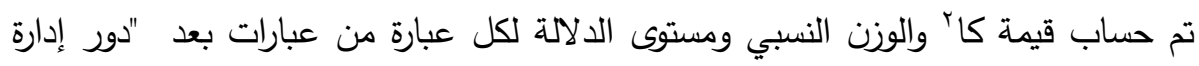

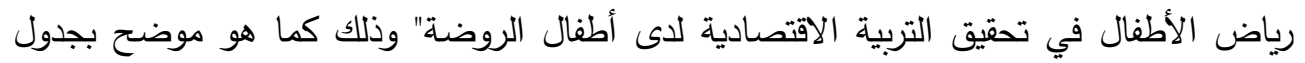

\section{جدول (ז)}

يوضح قيمة كا؟ والترتيب لاستجابات أفراد العينة حول بعد دور إدارة رياض الأطفال في تحقيق التربية الاقتصادية لاى أطفال الروضة مرتبة ترتيباً تنازليا

\begin{tabular}{|c|c|c|c|c|c|c|c|c|c|c|}
\hline \multirow[t]{4}{*}{ sis } & \multirow[t]{4}{*}{ الترتيب } & \multirow{4}{*}{ النسبي } & \multicolumn{6}{|c|}{ الاستجابات (ن=0 • ؛) } & \multirow[t]{4}{*}{ العبارات } & \multirow[t]{4}{*}{ م } \\
\hline & & & \multicolumn{6}{|c|}{ درجة الموافقة } & & \\
\hline & & & \multicolumn{2}{|c|}{ غير موافق } & \multicolumn{2}{|c|}{ موافق إلى حد ما } & \multicolumn{2}{|c|}{ موافق } & & \\
\hline & & & $\%$ & s & $\%$ & 5 & $\%$ & s & & \\
\hline *** $\leqslant \varepsilon \Gamma, q \vee$. & r & $r, \wedge$. & $\cdot, \mathrm{v}$ & $r$ & $i v, 0$ & $v_{1}$ & $\Lambda 1, v$ & ו וr & 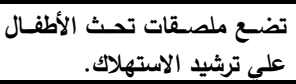 & 1 \\
\hline ***^r,Or & $\varepsilon$ & $r, \vee ५$ & 1,0 & 1 & $r \cdot, V$ & $\Lambda \varepsilon$ & $\vee v, \Lambda$ & Tlo & 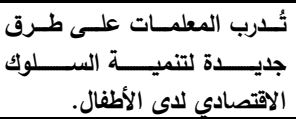 & r \\
\hline$* * \diamond \wedge \diamond, r \vee \wedge$ & 1 & $r, \wedge \wedge$ & $1, v$ & v & $\wedge, \varepsilon$ & r & $\wedge 9,9$ & צו & 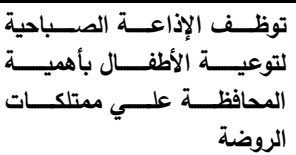 & $r$ \\
\hline ** * $\varepsilon 1 \leqslant$, Or & $r$ & r, ২^ & 1,0 & 7 & $1 \Lambda, 0$ & vo & $\wedge$. & E & 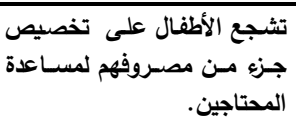 & \\
\hline *** & v & ץ, 79 & $\varepsilon, r$ & i & rY,O & 91 & $v r, r$ & rav & 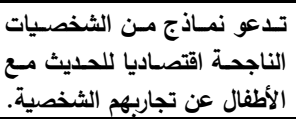 & 0 \\
\hline
\end{tabular}




\begin{tabular}{|c|c|c|c|c|c|c|c|c|c|c|}
\hline 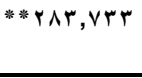 & $\wedge$ & ץ, १ & $\cdot, \mathrm{V}$ & $r$ & $r \cdot, \xi \varepsilon$ & Irr & $१ \wedge, q$ & rva & 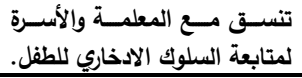 & 1 \\
\hline$* * r \cdot \wedge, q \Gamma r$ & - & $r, V$. & 1,0 & 1 & $r q, V$ & $1 \cdot 1$ & $v 1,9$ & ү१। & 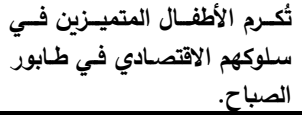 & $\mathrm{v}$ \\
\hline ***Y & 1. & $r, \Delta q$ & $\Gamma, \Gamma$ & $\begin{array}{l}1 \\
r\end{array}$ & $\Gamma \mu, \Lambda$ & Irv & זי & roo & تكلف الأطفال بعمل جمـاعي في & $\wedge$ \\
\hline 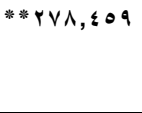 & 9 & Y,TV & $\cdot r$ & 1 & $r 1,9$ & $1 \times 9$ & $7 v, 9$ & rVo & 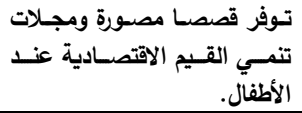 & 9 \\
\hline$* * r \cdot \Lambda, q \mu r$ & مم & $r, v$. & 1,0 & 1 & $r q, V$ & $1 \cdot 1$ & $v 1,9$ & ral & 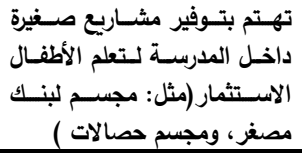 & 1. \\
\hline
\end{tabular}

ومن جدول (r) السابق يتضح وجود فروق ذات دلالة إحصائية عند مستوى (1 ب., •) بين

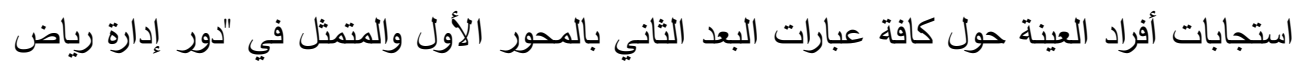
الأطفال في تحقيق التربية الاقتصادية لأطفال الروضة" حيث بلغ مستوى دلاتلة كافة البدات العبارات ( (1 ...)، وقد كانت كافة الفروق لصالح أصحاب الاستجابات (موافق). وقد جاء ترتيب عبارات هذا البعد حسب الوزن النسبي لها على النحو التالي:

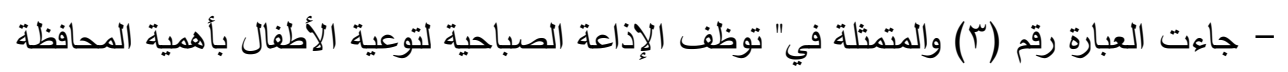

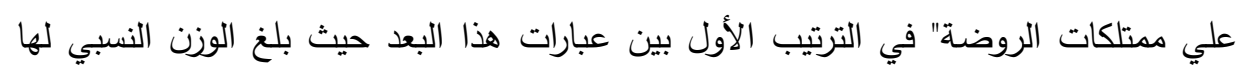

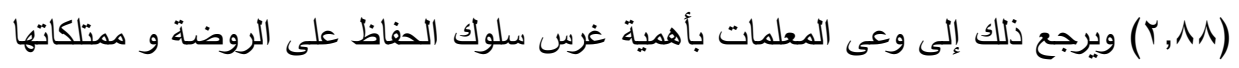

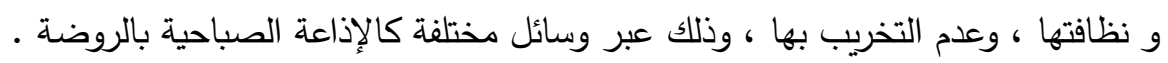

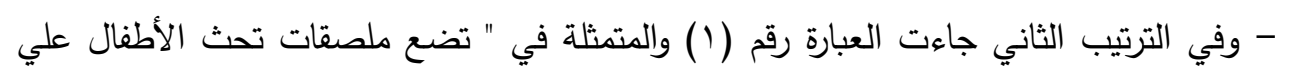

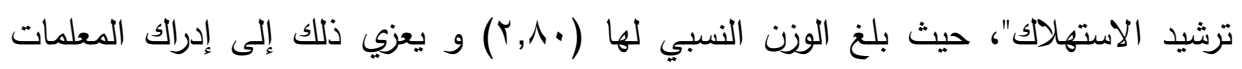

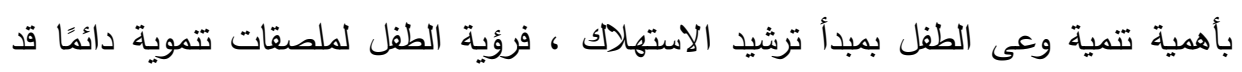
يساعده على تتمية وعى الطفل بعمليات الترشيد مثل غلق الصنبور بعد الاستخدام مباشرة

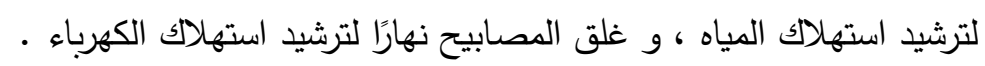

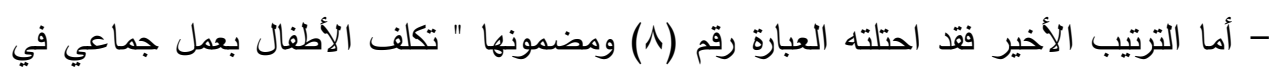

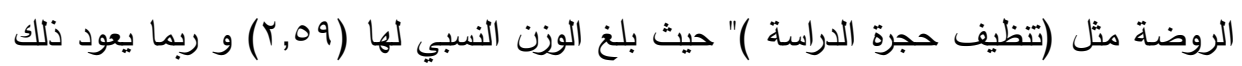

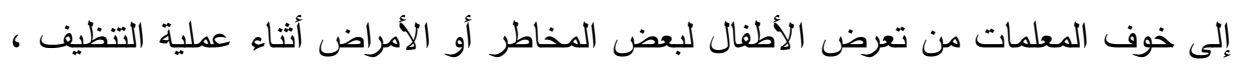

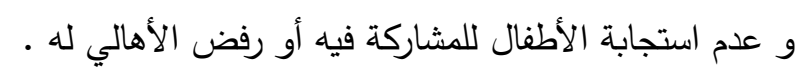


البعد الثالث: دور مناهج رياض الأطفال في تحقيق التربية الاقتصادية لاى أطفال الروضة.

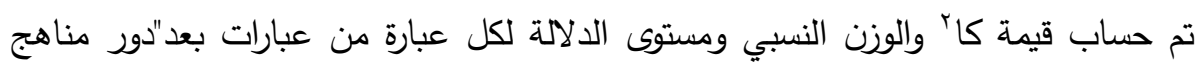

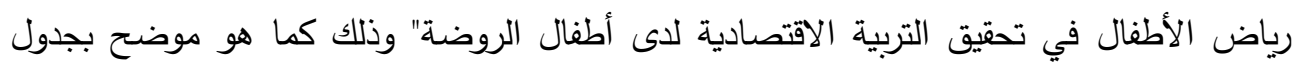

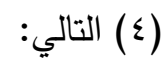

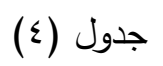

يوضح قيمة كا` والترتيب لاستجابات أفراد العينة حول بعد دور مناهج رياض الأطفال في تحقيق

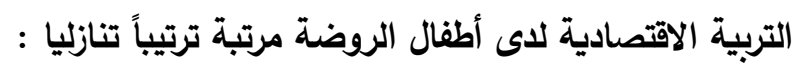

\begin{tabular}{|c|c|c|c|c|c|c|c|c|c|c|}
\hline \multirow[t]{4}{*}{ SاY } & \multirow[t]{4}{*}{ الترتيب } & \multirow{4}{*}{ 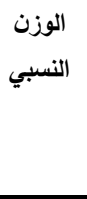 } & \multirow{2}{*}{\multicolumn{6}{|c|}{ الاستجابات (ن=ه • ـ ؛) }} & \multirow[t]{4}{*}{ العبارات } & \multirow[t]{4}{*}{ P } \\
\hline & & & & & & & & & & \\
\hline & & & \multicolumn{2}{|c|}{ غير موافق } & \multicolumn{2}{|c|}{ موافق إلى حد ما } & \multicolumn{2}{|c|}{ موافق } & & \\
\hline & & & $\%$ & s & $\%$ & 5 & $\%$ & s & & \\
\hline **FY & 1. & $r, r)$ & $r, r$ & 9 & $r \leq$ & १V & $v r, \Lambda$ & rqq & 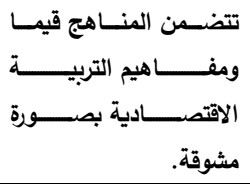 & 1 \\
\hline \& & $r$ & $r, \wedge 0$ & $\cdot, 0$ & $r$ & $1 \%, 4$ & 00 & $\wedge \bullet, q$ & $r \leqslant \wedge$ & 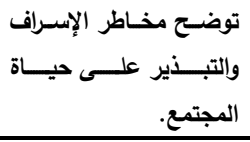 & $r$ \\
\hline$* * \Delta V \leq,, \triangle \leq \varepsilon$ & 1 & $\curlyvee, \wedge \wedge$ & $\cdot, r$ & 1 & $1 \cdot, 4$ & $\varepsilon r$ & $\wedge q, 1$ & MI & تنظيم الوقت وعي الطفل بأهمية & $r$ \\
\hline$* * \varepsilon, r, r \backslash 1$ & 7 & $r, \vee \wedge$ & $\cdot, r$ & 1 & r & 10 & $\vee \wedge, \wedge$ & 19 & 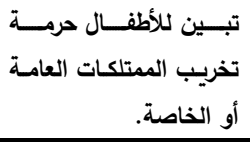 & $\varepsilon$ \\
\hline$* * \varepsilon \curlyvee q, \wedge \wedge 1$ & • & $\uparrow, \Lambda$. & $\cdot, 0$ & $r$ & $1 \wedge, \wedge$ & VI & $\Lambda \cdot, v$ & rrV & شراء الأثشياء الضرورية. إلى ضرورة & $\bullet$ \\
\hline$* * r v r, \varepsilon r v$ & 9 & r, Vo & $r$ & $\wedge$ & $r \cdot, v$ & $\Lambda \varepsilon$ & $v V, r$ & rit & الادخار ( مثل: قصة سيلة توضح قيمة & 7 \\
\hline
\end{tabular}




\begin{tabular}{|c|c|c|c|c|c|c|c|c|c|c|}
\hline & & & & & & & & & طعامها كالنملة والجمل) . & \\
\hline$* * \varepsilon, Y, Y \Psi V$ & T & r,VA & 1 & $\varepsilon$ & r. & $\wedge 1$ & va & rr. & تؤد تطيق على قواعد السللامة & $v$ \\
\hline$* * \varepsilon \cdot \wedge, 1 \cdot \varepsilon$ & م7 & $r, \vee \wedge$ & $\cdot, 0$ & r & $r \cdot, r$ & Ar & $v a, r$ & rr & 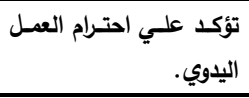 & $\wedge$ \\
\hline$* * \bullet \diamond,, \wedge \bullet q$ & r & $\curlyvee, \wedge \vee$ & $\cdot, r$ & 1 & 11,9 & $\leqslant \wedge$ & $\wedge \vee, q$ & roy & 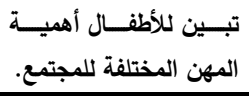 & 9 \\
\hline$* * \leqslant 0,, \vee \vee$. & $\varepsilon$ & $r, \wedge !$ & 1 & $\varepsilon$ & 17,1 & 71 & $\Lambda r, r$ & עזי & 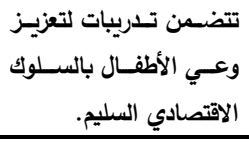 & 1. \\
\hline
\end{tabular}

ومن الجدول (ء) السابق يتضح وجود فروق ذات دلالة إحصائية عند مستوى (1 +, •) بين

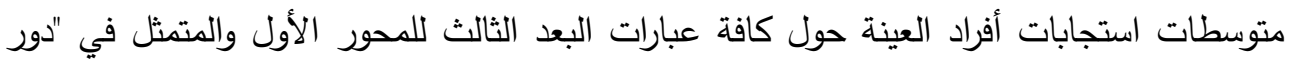
مناهج رياض الأطفال في تحقيق التربية الاقتصادية لدى أطفال الروضة" حيث بلغ مدات مستوى دلالمة

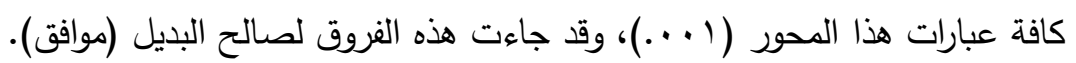
وقد جاء ترتيب عبارات هذا المحور حسب الوزن النسبي لها على النحو التالي:

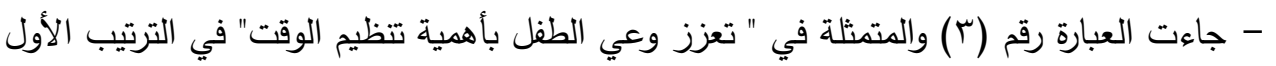

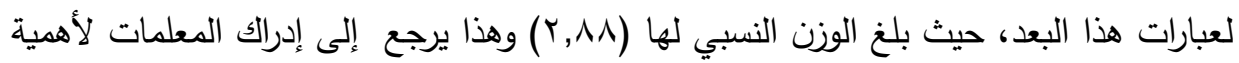
غرس مهارة تنظيم الوقت و إدراك قيمته لاى الطفل ، عن طريق تعليم الأطفال كيفية تنظيم الطيا الوقت و استغلاله بطريقة صحيحه لأن هذا سينعكس على شخصيته في المستقبل فإذا ما تعلم تتظيم الوقت بشكل فعال و سليم ، فإنه سيصبح شخصية ناجحة لا لانه محاله .

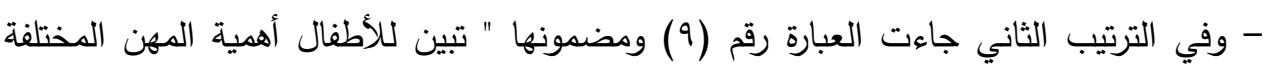
للمجتمع" حيث بلغ الوزن النسبي لها (r,AV) و يعود ذلك إلى ألى أهمية توعية الطفل بأهية

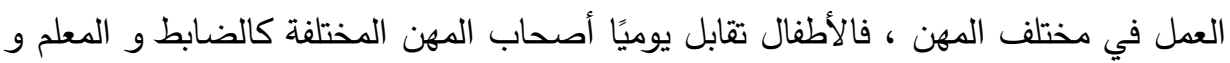
السائق و التاجر و الطبيب و غيره ، مما ينعكس بالإيجاب نحو تقدير الطفل لهذا العمل و أصحاب هذه المهن أستو - أما الترتيب الأخير فقد احتلته العبارة رقم (1) ومضمونها " تتضمن المناهج قيما ومفاهيم التربية الاقتصادية بصورة مشوقة" حيث بلغ الوزن النسبي لها (Y,Y (Y) و يعود ذلك الى إهمال

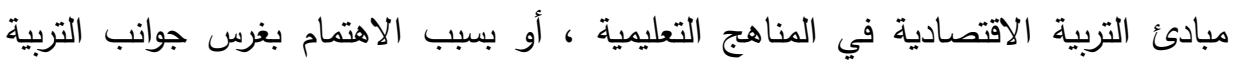

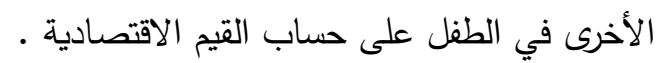


البع الرابع: دور أنثطة رياض الأطفال في تحقيق التربية الاقتصادية لاى أطفال الروضة.

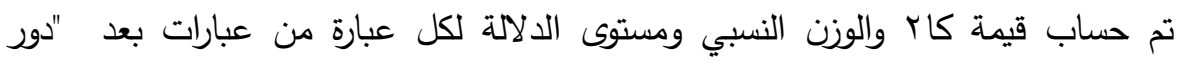

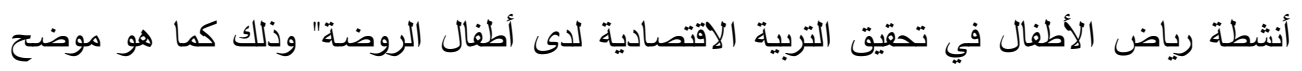

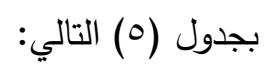

\section{جدول (0) جاون}

يوضح قيمة كا؟ والترتيب لاستجابات أفراد العينة حول بعد دور أنثطة رياض الأطفال في تحقيق الاقيق

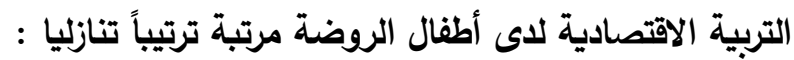

\begin{tabular}{|c|c|c|c|c|c|c|c|c|c|c|}
\hline \multirow[t]{4}{*}{ كاr } & \multirow[t]{4}{*}{ الترتيب } & \multirow{4}{*}{ المزبي } & \multirow{2}{*}{\multicolumn{6}{|c|}{ الاستجابات (ن=ه • ؛ ) }} & \multirow[t]{4}{*}{ العبارات الع } & \multirow[t]{4}{*}{ 5 } \\
\hline & & & & & & & & & & \\
\hline & & & \multicolumn{2}{|c|}{ غير موافق } & \multicolumn{2}{|c|}{ موافق إلى حد ما } & \multicolumn{2}{|c|}{ موافق } & & \\
\hline & & & $\%$ & s & $\%$ & 5 & $\%$ & $s$ & & \\
\hline$* * \varepsilon \leqslant r, q \vee$. & • & $\uparrow, \wedge$. & $\cdot, \mathrm{V}$ & $r$ & $i v, 0$ & vi & $\Lambda 1, v$ & ו וr & 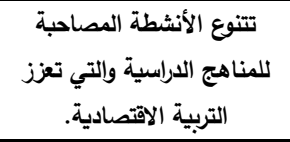 & 1 \\
\hline$* * 0 \leq 1, \vee \neg 4$ & r & $\curlyvee, \wedge \vee$ & $\cdot, r$ & 1 & Ir,r & o. & $\wedge \vee, \varepsilon$ & ros & 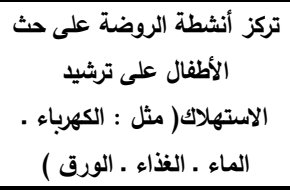 & $r$ \\
\hline$* * \because q \uparrow, 1 \vee$. & $r$ & $\curlyvee, \wedge \varepsilon$ & $\cdot, 0$ & r & $1 \varepsilon, 1$ & $\uparrow$. & $\wedge \varepsilon, \vee$ & $r \leqslant r$ & تحث الأنثطة القصصية على & $r$ \\
\hline$* * \leqslant \uparrow r, \neg \ldots$ & $\varepsilon$ & r,Ar & $\cdot, \mathrm{v}$ & $r$ & $17, r$ & 74 & AT & צrr & بتعزيز احترام المهن المختلفة المسرحية. & $\varepsilon$ \\
\hline$* * \varepsilon \varepsilon,, I r r$ & مم & $\curlyvee, \wedge$. & $\cdot, \mathrm{v}$ & $r$ & $i v, \Lambda$ & Vr & $\wedge 1,0$ & rr. & تثجع الأركان التعليمية على & 0 \\
\hline$* * \Gamma \Delta \Delta, r \leq \varepsilon$ & $\wedge$ & $Y, Y \leq$ &., 0 & r & $r \varepsilon, r$ & 91 & $v_{0, r}$ & $r .0$ & 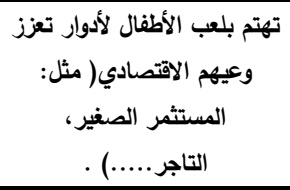 & 7 \\
\hline 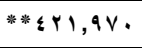 & $v$ & $r, v q$ & 1,0 & 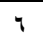 & 11 & & $\wedge ., 0$ & דו & توفر أنثطة متنوعة لتدريب & $v$ \\
\hline
\end{tabular}




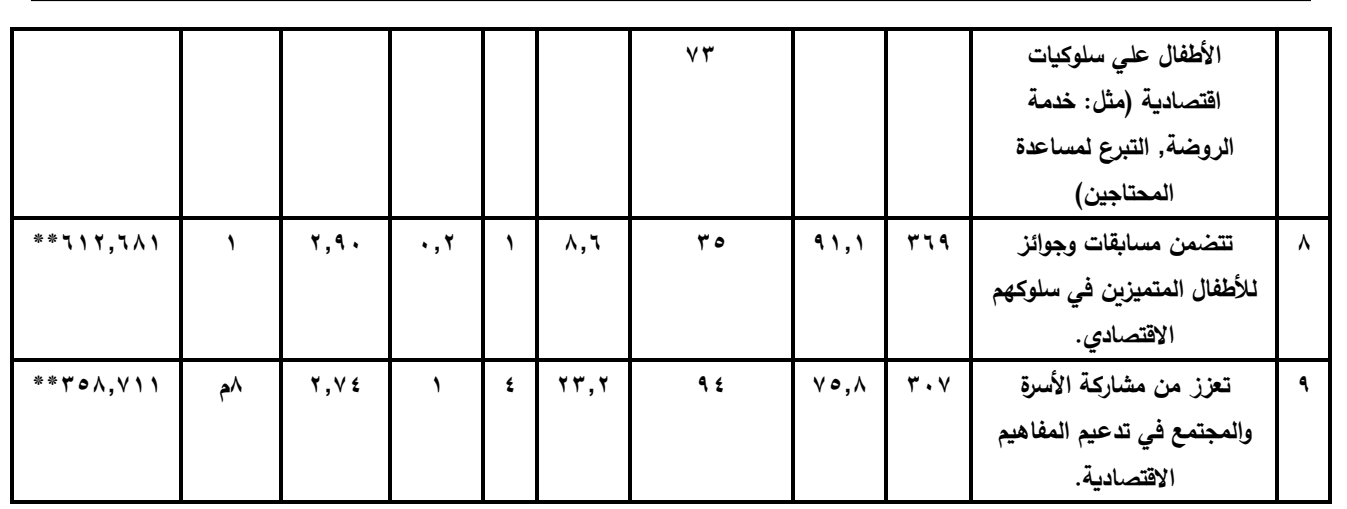

ومن جدول (0) السابق يتضح وجود فروق ذات دلالة إحصائية عند مستوى (1 .,.•) بين

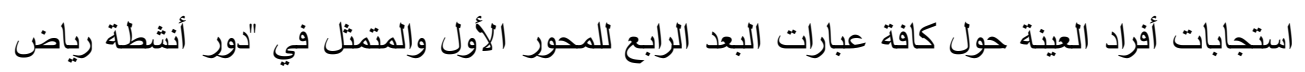

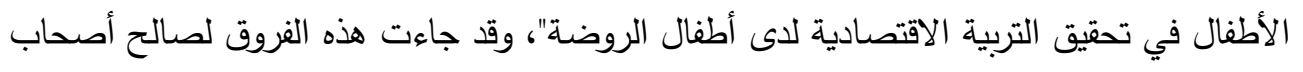

$$
\text { الاستجابات (موافق). }
$$

$$
\text { وقد جاء ترتيب عبارات هذا البعد حسب الوزن النسبي لها على النحو التالي: }
$$

- جاءت العبارة رقم (^) والمتمثلة في " تتضمن مسابقات وجوائز للأطفال المتميزين في سلوكهم لتوني

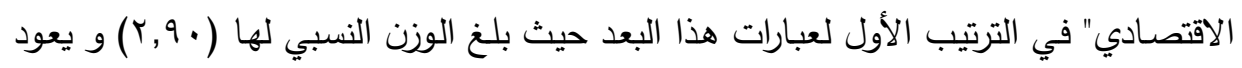
ذلك إلى إدراك المعلمة أن التعزيز الإيجابي هو الحئ أحد أهم الوسائل الفعالة في التأثير على الطفل

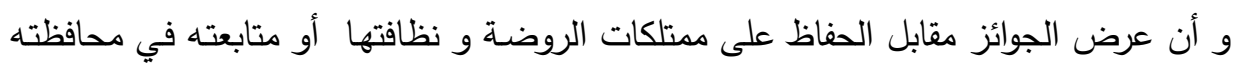

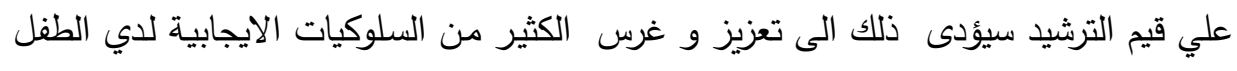
- وفي الترتيب الثاني جاءت العبارة رقم (Y) والمتمثلة في " تركز أنشطة الروضـة على حث

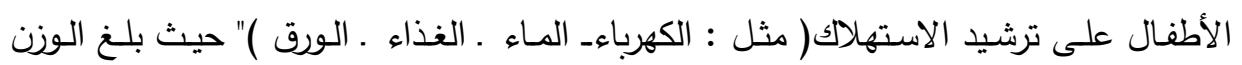

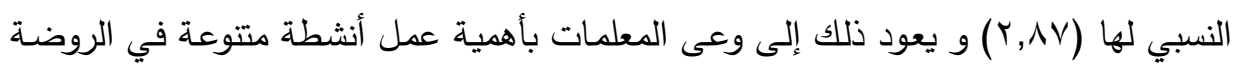

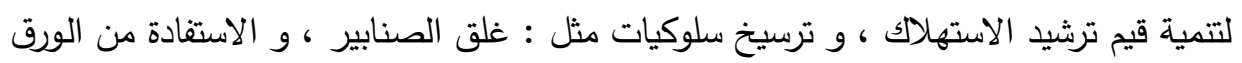

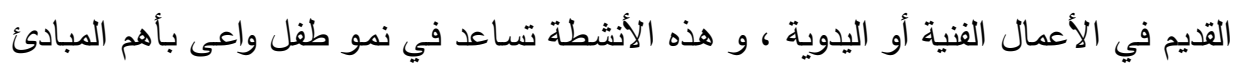

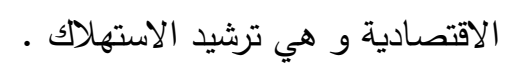

أما الترتيب الأخير فقد احتلته العبارتين (آ, 9) ومضمونها " تهتم بلعب الأطفال لأدوار تعزز وعيهم الاقتصادي (مثل: المستثمر الصغير, التاجر .....) , "تعزز من مشاركة الأسرة

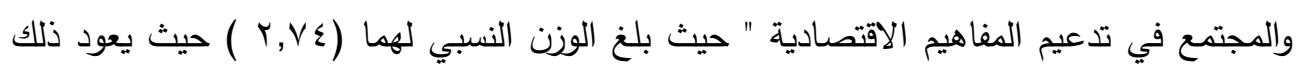


إلي عجز المعلمات عن استخدام لعب الأدوار في تحقيق هدف معين مثل التربية الاقتصادية للطفل

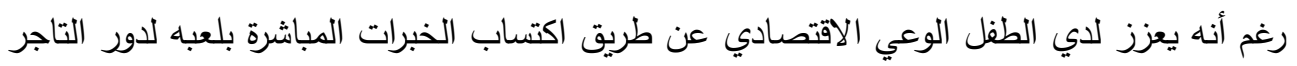

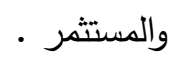

$$
\text { نتائج البحث : }
$$

تمثلت أبرز نتائج واقع دور مؤسسات رياض الأطفال في تحقيق التربية الاقتصادية في

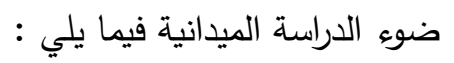

- تتضمن محور واقع دور مؤسسات رياض الأطفال في تحقيق التربية الاقتصـادية لاى أطفال الروضة أربعة أبعاد رئيسية تمثلت في دور معلمات رياض الأطفال , دور إدارة رياض الاض الأطفال

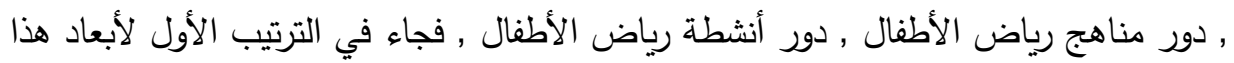

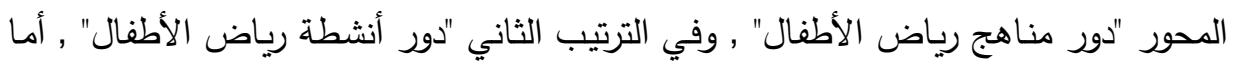

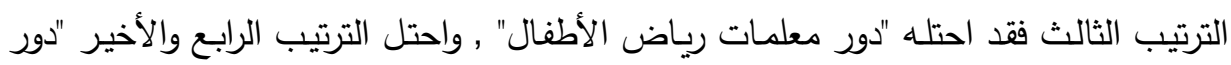
إدارة رياض الأطفال" و جاءت جميعها بدرجة(موافق) .

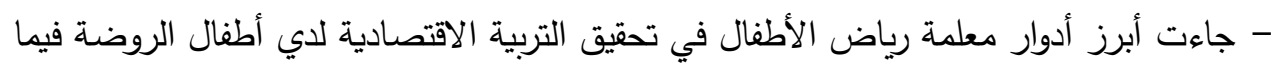

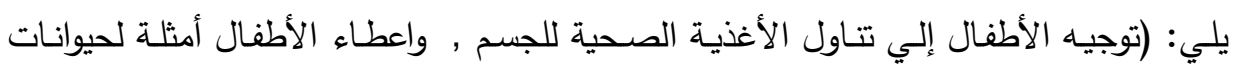
تدخر طعامها , وحث الأطفال على المحافظة علي الممتلكات العامة والخاصة ).

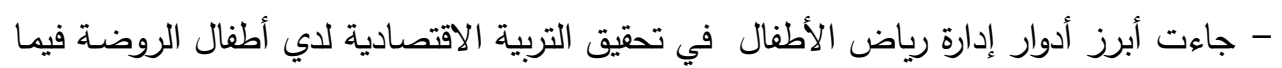

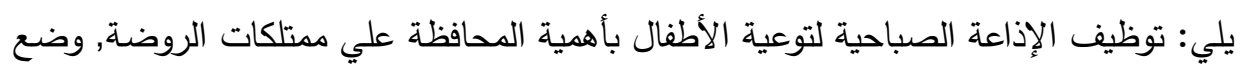

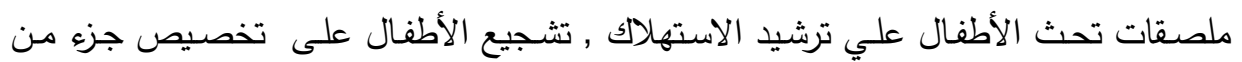
مصروفهم لمساعدة المحتاجين. - جاءت أبرز أدوار مناهج رياض في تحقيق التربية الاقتصادية لدي أطفال الروضـة فيما يلي:

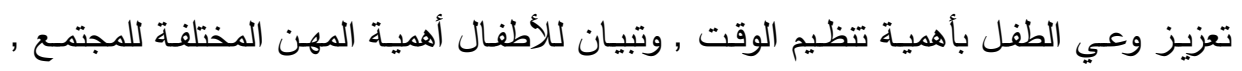

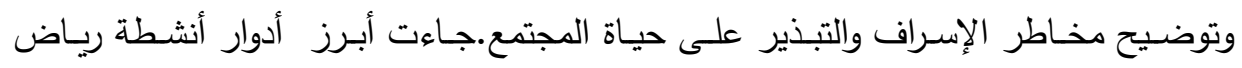

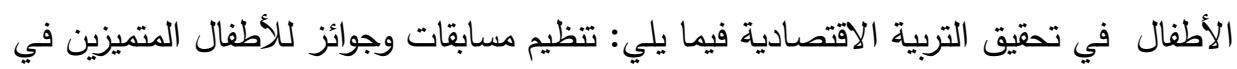
سلوكهم الاقتصادي , تركيز أنشطة الروضسة على حث الأطفال على ترشيد الاستهلاك, حث

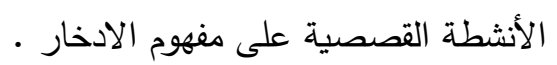
توصيات البحث :

- توعية القائمين علي العملية التعليمية بأهمية الاهتمام بالتربية الاقتصادية في مناهج الروضة - تطوير مناهج الروضة بحيث تتمي وتدعم القيم الاقتصادية . 
- تكلف الروضة الأطفال ببعض الأعمال التي تسهم في تتمية القيم الاقتصادية لديهم كالمشاركة في تنظيف وتزيين حجرة الدراسة . - ممارسة عملية للأطفال علي السلوكيات الاقتصادية للمحافظة علي الممتلكات العامة والخاصة

- الاتصال والتعاون بين الروضة والمؤسسات التربوية الأخرى كالأسرة ووسائل الإعلام .

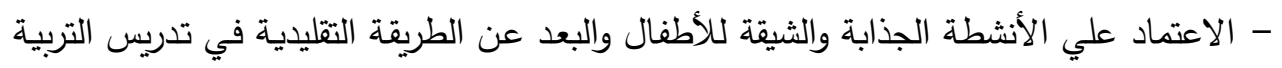
الاقتصادية .

- إقامـة دورات تدريبية خاصـة بالمجال الاقتصـادي لموجهات ريـاض الأطفال لمسـاعدة المعلمـة علي تدريس التربية الاقتصادية بالأساليب الحديثة الجاذبة للأطفال . - إغناء مكتبة الروضة بالقصص الثيقة التي تحقق التربية الاقتصادية .

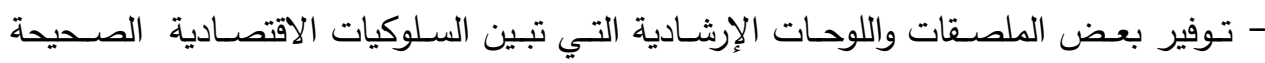

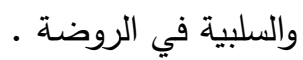
- عقد دورات وندوات للمعلمات لتعريفه بأهمية التربية الاقتصادية للأطفال وتزويدهم بالأنشطة

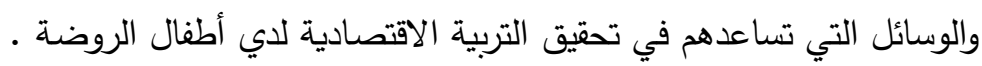

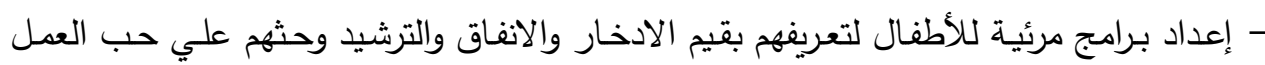
وأهميته وكيفية الدحافظة علي الممتلكات العامة . - إقامة معارض داخل الروضة وخارجها لتشجيع أعمال الأطفال اليدوية وغرس قيمة حبـ حب العمل - تسـهيل الإجـراءات للمعلمـات للـرحلات والزيـارات الميدانيـة التي تتمـي قيم المحافظـة علـي المتلكات العامة وقيم التعرف علي المهن المختلفة . - إقامة ندوات لبعض المتخصصين في مجال التربية الاقتصادية بحضور أولياء أمور الأطفال

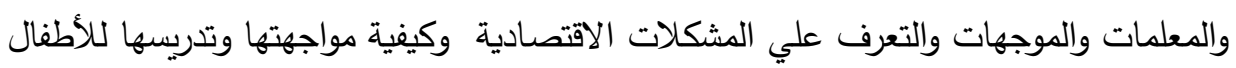

- زيارة المتخصصين في مجال الطفولة والاقتصاد ومناقثة الأطفال بطريقه بسيطة لأهمية التربية الاقتصادية وأهمية تجنب السلوكيات الاقتصادية السلبية وتعزيز السلوكيات الاقتصادية الإيجابية قائمة المر اجع 


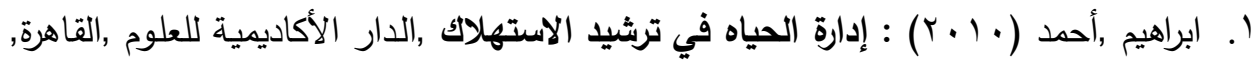
مصر

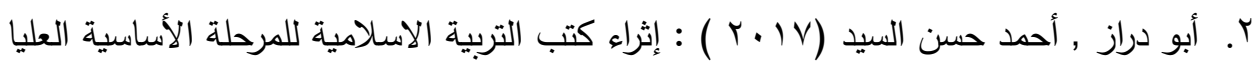
بمفاهيم التربية الاقتصادية , رسالة ماجستير غير منشورة , كلية التربية , الجامعة الاسلامية . غزة .

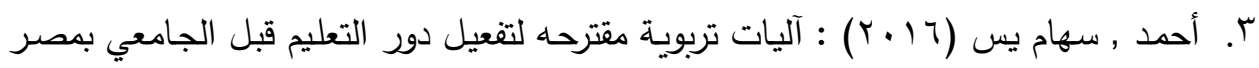

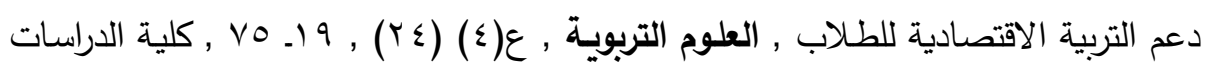
العليا للتربية , جامعة القاهرة . ع. أحمد ,غادة محمد (10 ب ب) : دور التربية في تتمية بعض القيم الداعمة للتتمية الاقتصادية

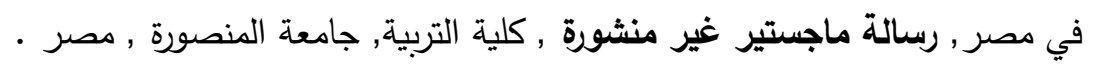

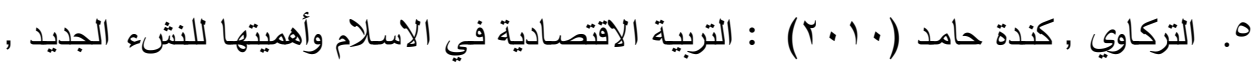

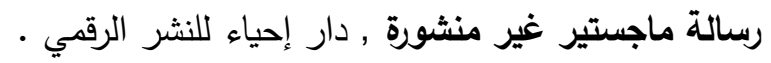

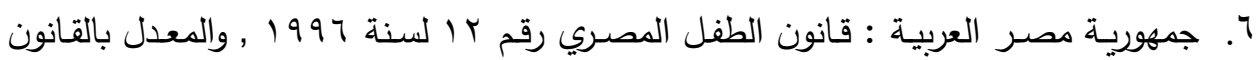

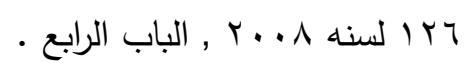

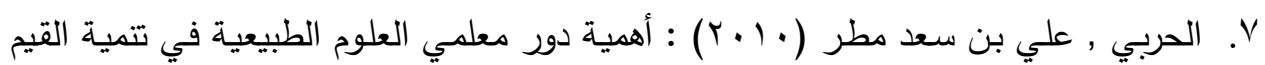

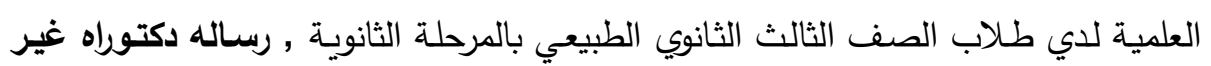
منشورة , كلية التربية , جامعة أم القري, المملكة العربية السعودية.

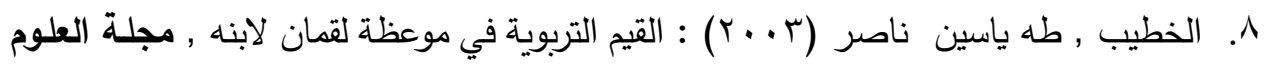

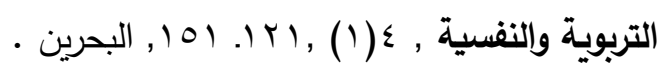

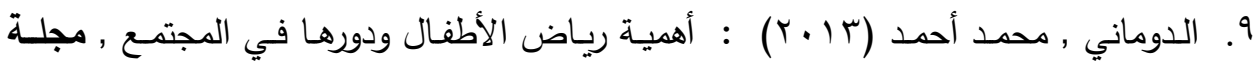

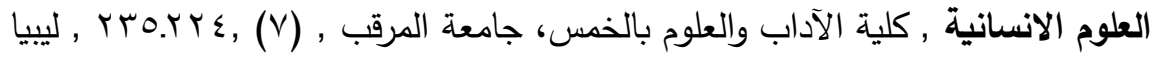

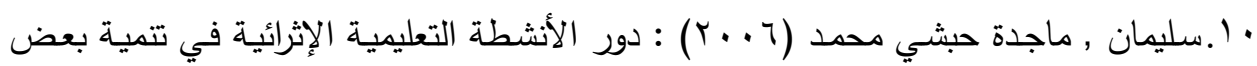
عمليات العلم والتحصيل المعرفي لاى تلاميذ الصف الرابع الابتدائي في مادة العلوم , المجلة

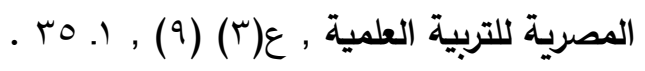

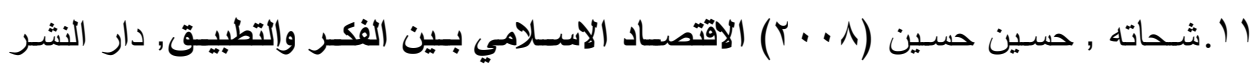
للجامعات , القاهرة . 


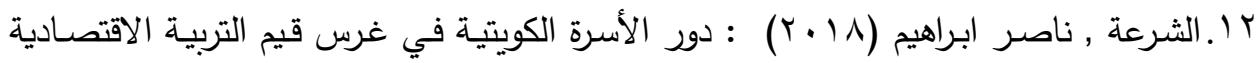

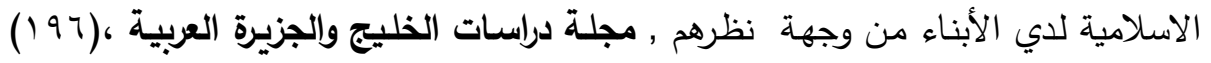

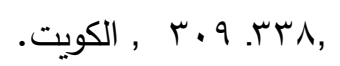

rا.طايع , فيصل الراوي رفاعي (•99 (19) : التربية الاقتصادية لطفل المدرسة الابتدائية ,المجلة

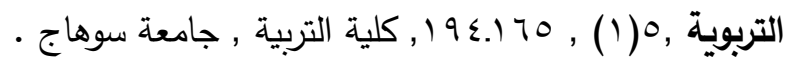

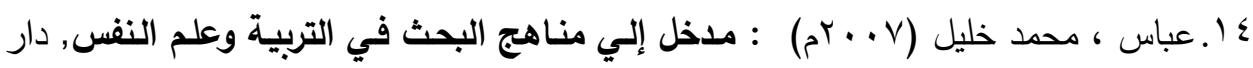
المسيرة, عمان.

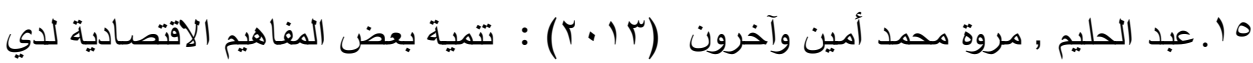

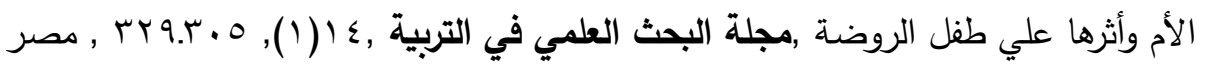
7 ا. عبد الموجود ، أحمد (7 ا • rم) : دور الأسـرة في تثكيل هويـة الطفل البدوي في سيناء

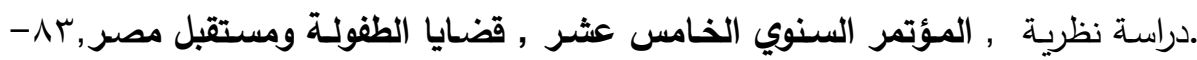
V V I ا القاهرة.

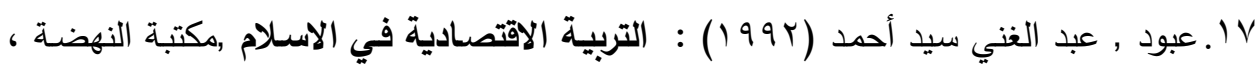
القاهرة. 1). عشرية , إخـلاص حسن السيد (11 ب) : الأنشطة التربويـة في ريـاض الأطفال كمرتكز

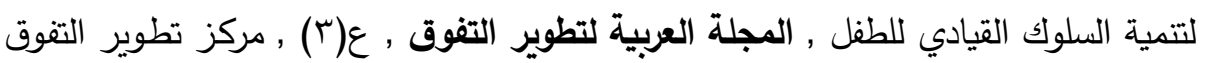

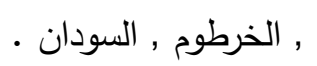

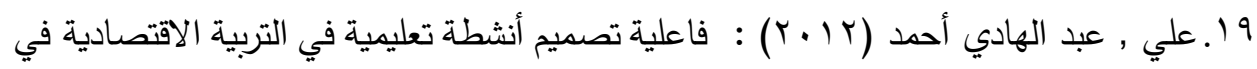
تتمية التحصيل والوعي الاقتصادي لاى تلاميذ المدرسة الابتدائية , مجلة التربية , جامعة

$$
\text { الأزهر , (1) (1) , (1) }
$$

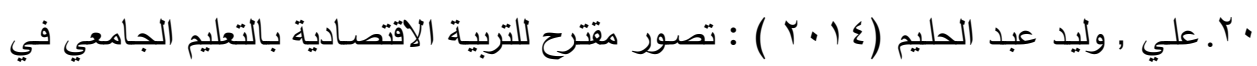

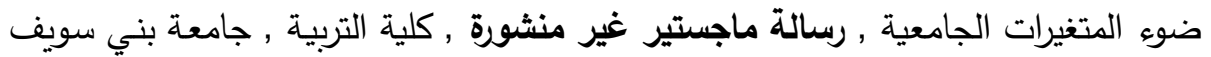

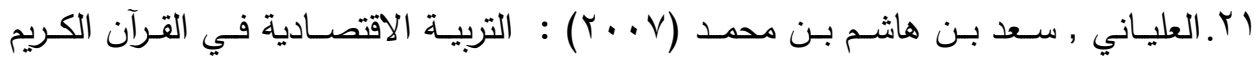
وتطبيقاتها في الأسرة والمدرسة , رسالة دكتوراه غير منشورة , كلية التربية جامعة ام القري ,

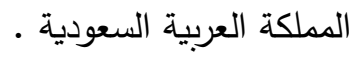




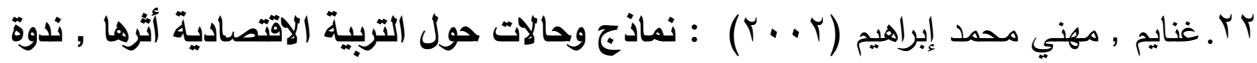

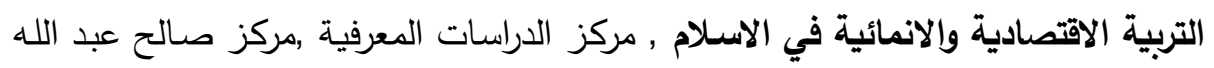

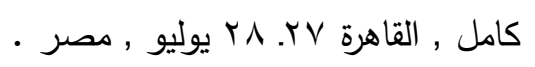

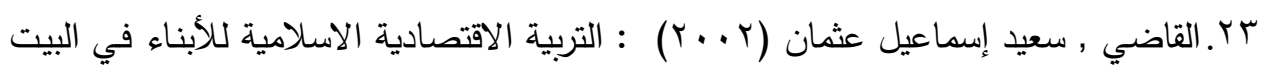

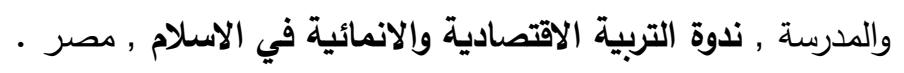

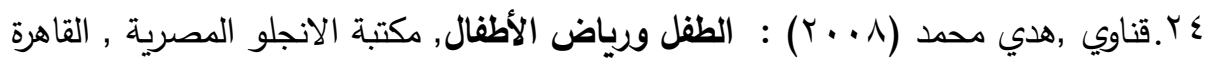

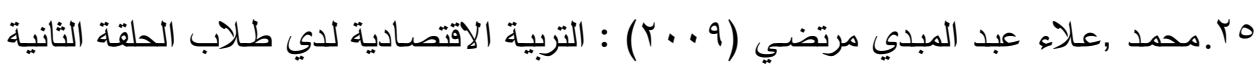
من مرحلة التعليم الاساسي ـواقعها ـ معوقاتها دراسة ميدانية, رسالة ماجستير منشورة , كلية

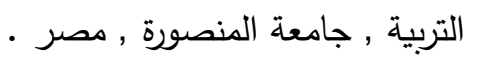

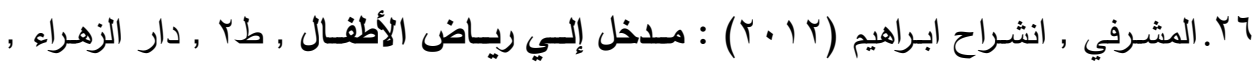

$$
\text { الرياض }
$$

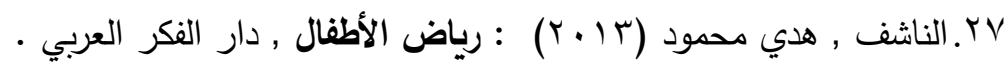

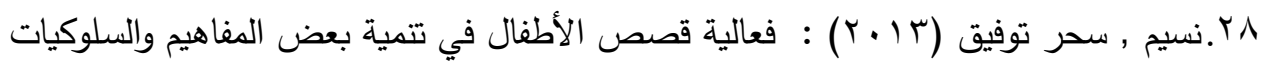

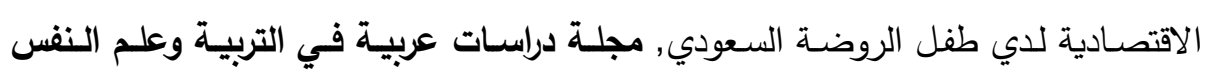

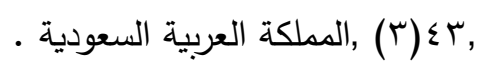

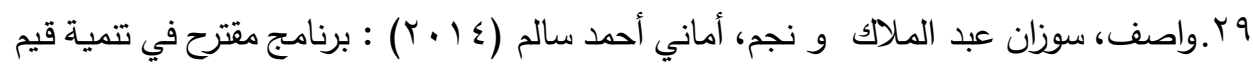
ترشيد الاستهلاك لطفل الروضة وأثثر على سلوكه الاستهلاكي , مجلة بحوث التربية النوعية ,

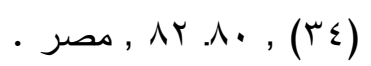

30 Mayasari (2015). Feminist Economy in Family Economic Education to Build Economic Morality of Pancasila, IOSR Journal of Economics and Finance. (6) 5, 35.40

31 Beverly, Armento (1983). A study of the basic economic concepts, Journal of economic education, 14 (3).22 
